Bentham OPen
CrossMark
Content list available at: www.benthamopen.com/TOORTHJ/
DOI: $10.2174 / 1874325001610010877$

REVIEW ARTICLE

\title{
Carbon Nanostructures in Bone Tissue Engineering
}

\author{
Brian Lee Perkins ${ }^{1, *}$ and Naghmeh Naderi ${ }^{2,3}$ \\ ${ }^{1}$ Health Informatics Group, Swansea University Medical School, Swansea, SA2 8PP, United Kingdom \\ ${ }^{2}$ Reconstructive Surgery \& Regenerative Medicine Group, Institute of Life Science (ILS), Swansea University Medical \\ School, Swansea, SA2 8PP, United Kingdom \\ ${ }^{3}$ Welsh Centre for Burns \& Plastic Surgery, Abertawe Bro Morgannwg University Health Board, Swansea, United \\ Kingdom
}

Received: October 16, 2015

Revised: November 15, 2015

Accepted: May 31, 2016

\begin{abstract}
:
Background:

Recent advances in developing biocompatible materials for treating bone loss or defects have dramatically changed clinicians' reconstructive armory. Current clinically available reconstructive options have certain advantages, but also several drawbacks that prevent them from gaining universal acceptance. A wide range of synthetic and natural biomaterials is being used to develop tissueengineered bone. Many of these materials are currently in the clinical trial stage.
\end{abstract}

\section{Methods:}

A selective literature review was performed for carbon nanostructure composites in bone tissue engineering.

\section{Results:}

Incorporation of carbon nanostructures significantly improves the mechanical properties of various biomaterials to mimic that of natural bone. Recently, carbon-modified biomaterials for bone tissue engineering have been extensively investigated to potentially revolutionize biomaterials for bone regeneration.

\section{Conclusion:}

This review summarizes the chemical and biophysical properties of carbon nanostructures and discusses their functionality in bone tissue regeneration.

Keywords: Bone tissue engineering, Carbon nanostructures, Composites, Bone reconstruction.

\section{INTRODUCTION}

A large clinical need exists for bone reconstruction, including underlying conditions and causes such as high-energy trauma (e.g. road traffic accidents), tissue degeneration (e.g. osteoporosis), infection (e.g. osteomyelitis), and developmental deformities [1]. In trauma and orthopaedic surgery, extended bone loss is associated with considerable technical and physiological issues. In the quest for alternative therapeutic strategies, research is focusing on the concept of tissue engineering to assist the progress of bone tissue regeneration.

Advantageous translation of tissue engineering strategies to several surgical specialties has motivated clinicians to adopt these approaches in bone tissue engineering of defects $[2,3]$. The elemental approach underlying tissue

\footnotetext{
* Address correspondence to this author at the Health Informatics Group, Swansea University Medical School, Swansea, SA2 8PP, United Kingdom; Tel: +441792602865; E-mail: brianleeperkins@gmail.com
} 
engineering is to combine a biomaterial scaffold with cells, and/or biologically active cues to form a construct, which promotes regeneration of organs and tissues $[4,5]$. The biomaterial scaffold design should consider physicochemical properties, microstructure, and degradation in vivo. A suitable scaffold will (i) possess an interconnected porous structure with surface properties that are beneficiary for the adherence, growth and differentiation of appropriate cells and enable the exchange of nutrients and metabolic waste, and (ii) be biodegradable with a rate to compliment tissue growth and regeneration [6].

Currently, there is also a need for better filler materials that can be used in the reconstruction of large bony defects and implants that are mechanically robust and suited to their biological environment. A material measuring less than 100 nanometers $(\mathrm{nm})$ in at least one dimension is the widely accepted definition for a 'nano' particle, material or structure [7, 8]. Due to their unique properties, carbon nanostructures are being used for a variety of applications, including imaging, cancer therapy, drug delivery, and regenerative medicine $[9,10]$. Carbon nanostructures have special mechanical, electrical magnetic, optical, chemical, and other biological properties because of their high aspect ratio and large surface area [11 - 14].

In this review we discuss the currently available reconstructive options for bony defects, followed by currently available biomaterials and tissue engineering techniques. Furthermore, we discuss the use of carbon nanostructures which enhance biomaterials in bone tissue engineering.

\section{BONE RECONSTRUCTION}

The traditional methods for management of bony defects include autografting and allografting cancellous bone, distraction osteogenesis, and applying vascularized free tissue transfer of the fibula and iliac crest [15, 16]. Despite several advantages, a number of drawbacks are associated with their use [17 - 20]. The generalized properties of bone reconstruction interventions have been summarized in Table 1 including their biophysical properties, the relative risk to the patient, and the practicability of the intervention (i.e. availability and cost) [17 - 31]. The biggest shortfall of allografts, xenografts, demineralized bone matrix (DBM), and alloplasts is that they lack either osteoinductive and/or osteoconductive properties, and in some cases lead to disease transmission and/or rejection [17, 19, 22].

The osteogenic, osteoinductive, and osteoconductive properties of autografts are ideal, whereas their use is associated with minimal risk of infectious disease transmission [19]. Since bone grafts are avascular and dependent on diffusion, the size of the defect and the viability of the host bed can limit their application. Autografts have restricted availability and are often difficult to harvest, causing additional morbidity. In addition, insufficient integration of bony autografts may necessitate secondary surgical procedures. Volume maintenance of the new bone can also be problematical due to unforeseeable bone resorption.

By definition, an allograft is tissue harvested from one individual and transplanted in another of the same species [32]. Use of bone allografts has similar drawbacks as autograft except the associated donor site morbidity, but increases the risk of infectious disease transmission. Fresh-frozen or freeze-dried allografts are available as structural and morselized forms [33]. Allografts are osteoconductive and provide a scaffold framework for host tissue to grow in. Contrarily, it has moderate osteoinductive properties at best. Following implantation, the host is believed to ellicit a complex immune response $[33,34]$. Freeze-drying or freezing the allograft is imperative in restricting this immune reaction; although, the crucial osteoinductive, osteoconductive, and mechanical properties of the material may be reduced.

Vascularized bone transfers import vascularized tissue into the defect and can be used to bridge larger bone defects. They are, however, associated with significant donor site morbidity, limited availability, technical difficulties, and long operating times [35].

Distraction osteogenesis, a surgical procedure used to lengthen bone, entails a corticotomy to fracture the bone into two segments followed by distraction to allow osteogenesis in the gap. When distraction has led to the desired length, the bone is allowed to heal. This technique has the benefit of increasing the length of bone as well as the volume of the surrounding soft tissue. However, multiple procedures are required to achieve the desired results, considerable morbidity is caused to the patient, and there is a major risk of infection [36].

\subsection{Biomaterials in Bone Tissue Engineering}

Recent developments in the field of biomaterials and tissue engineering have led to many compounds and materials with a wide range of favourable properties to be used for implantation [37 - 39]. Oryan et al. have provided an excellent 
review on the classic options, as well as emerging biomaterials in bone tissue engineering; including a list of commercially available bone graft substitutes [17].

Table 1. Properties of bone reconstruction interventions.

\begin{tabular}{|c|c|c|c|c|c|c|c|c|c|c|}
\hline \multirow{3}{*}{$\begin{array}{l}\text { Bone } \\
\text { Reconstruction } \\
\text { Intervention }\end{array}$} & \multicolumn{10}{|c|}{ Relative Properties } \\
\hline & \multicolumn{5}{|c|}{ Biophysical Properties } & \multicolumn{3}{|c|}{ Risk to Patient } & \multicolumn{2}{|c|}{ Practicability } \\
\hline & \begin{tabular}{|c|} 
Osteo- \\
conductive
\end{tabular} & $\begin{array}{c}\text { Osteo- } \\
\text { inductive }\end{array}$ & $\begin{array}{c}\text { Osteo- } \\
\text { genic }\end{array}$ & $\begin{array}{c}\text { Osseo- } \\
\text { integration }\end{array}$ & \begin{tabular}{|c|} 
Structural \\
Framework
\end{tabular} & $\begin{array}{l}\text { Additional } \\
\text { Morbidity }\end{array}$ & \begin{tabular}{|c|} 
Disease \\
Transmission \\
\end{tabular} & Rejection & Availability & Cost \\
\hline $\begin{array}{l}\text { Cancellous autograft } \\
{[17,19,22]}\end{array}$ & +++ & $++/+++$ & +++ & +++ & $-/+$ & $++/+++$ & - & - & + & $++/+++$ \\
\hline $\begin{array}{l}\text { Cortical autograft }[17, \\
19,22]\end{array}$ & $++/+++$ & $++/+++$ & $++/+++$ & +++ & +++ & $++/+++$ & - & - & $+/++$ & $++/+++$ \\
\hline $\begin{array}{l}\text { Distraction } \\
\text { osteogenesis [23 - 26] }\end{array}$ & $+/+++$ & $++/+++$ & $++/+++$ & N/A & N/A & $+/++$ & - & N/A & + & $++/+++$ \\
\hline Allograft $[17,19,22]$ & $+/+++$ & $-1+$ & - & $++/+++$ & $-/+++$ & - & + & $+/++$ & $+/+++$ & $+/+++$ \\
\hline Xenograft [17] & $+/+++$ & + & - & $++/+++$ & $-/+++$ & - & ++ & +++ & $++/+++$ & $+/++$ \\
\hline $\begin{array}{l}\text { Deminieralized bone } \\
\text { matrix }[17,19]\end{array}$ & $+/+++$ & ++ & $++/+++$ & $++/+++$ & $-/+++$ & - & + & $+/++$ & $++/+++$ & $+/++$ \\
\hline Alloplasts $[17,19]$ & $+/+++$ & $-1++$ & - & $++/+++$ & $-1++$ & - & - & $-1+$ & +++ & + \\
\hline Polymers [27 - 29] & $++/+++$ & $++/+++$ & $++/+++$ & $++/+++$ & $+/++$ & - & - & - & $+/+++$ & $+/+++$ \\
\hline $\begin{array}{l}\text { Carbon nanostructure } \\
\text { composites }[30,40- \\
43]\end{array}$ & $++/+++$ & $++/+++$ & $++/+++$ & $++/+++$ & $++/+++$ & - & - & - & $+/+++$ & $++/+++$ \\
\hline Optimal intervention & +++ & +++ & +++ & +++ & +++ & - & - & - & +++ & + \\
\hline
\end{tabular}

Relative properties are subjectively graded by the authors based on the literature referenced. Grey shading in each cell highlights the shortcomings of each bone reconstruction intervention. 'Optimal intervention' is suggested by the literature [17, 19]. Osteoconductivity is the ability of new bone cells/colonise and spread [19]. Osteoinductivity is the ability/stimulate or promote bone formation [18, 19]. Osteogenicity is the presence of boneforming cells within the bone graft $[19,20]$. Osseointegration is the formation of bony tissue around the implant without the growth of fibrous tissue at the bone-implant interface [44]. N/A $=$ Not applicable, $-=$ none, $/=$ range, $+=$ low,$++=$ moderate, $+++=$ high, $(e . g .++/+++$ means moderate to high).

Bone with its complex molecular and anatomical components can be analysed as a 'composite' material. It consists of collagen, bone mineral, and water. The mineral component can be approximated as hydroxyapatite (HA) with the molecular formula: $\left.\mathrm{Ca}_{10}\left(\mathrm{PO}_{4}\right)_{6}(\mathrm{OH})_{2}\right)$, which in addition incorporates silicon, carbonate, and zinc. Some biomaterials currently used for bone regeneration aim to mimic its molecular microenvironment. Furthermore, the main function of bone is loadbearing and structural support. It has a high elastic Young's Modulus ranging from 12 to 18 GPa [27].

To date, metals have been preferably selected as structural implants to replace or reinforce bone owing to their superior mechanical properties. The majority of the materials are, however, not suitable for implantation due to the host's poor tolerance of dissolution products. Currently acceptable materials are based on titanium, cobalt, iron, nickel, zirconium, tantalum, gold and silver. Alloys have been made of these base metals aiming to improve their properties, including ultimate strength, elastic modulus, fabricability, ductile behaviour, and corrosion resistance. There are three alloy systems available: titanium alloys, stainless steel (chromium, iron, and molybdenum), and cobalt-chromium. These metallic implants, however, have many drawbacks including stress shielding, which may result in bone atrophy and osteoporosis, palpability, risk of infection, extrusion, and particulate leaching [45 - 47].

DBM is derived from allograft bone and prepared by pulverization of bone to a specific size. This process is followed by acid extraction of the mineralized part of bone [33,34, 48], resulting in a mixture of collagen, growth factors, and proteins [48, 49]. In addition, different carriers, such as HA, glycerol, gelatin, and calcium sulfate can be added to the composite $[48,50]$. DBM does not provide mechanical support, although its osteoconductive properties are highly desirable. It has superior osteoinductive properties compared to allograft bone due to the release of growth factors during the demineralization phase [33, 34].

Many other non-metallic materials have been investigated for implantation in bony defects, including bioglasses and ceramics, as well as polymers such as polymethylmathacrylate (PMMA) and ultrahigh molecular weight polyethylene (UHMW-PE). PMMA is mainly used to affix implants. Although adhesive, it does not bond to either the bone or the implant. UHMW-PE, applied as a biomaterial for orthopaedic implants, has a low coefficient of friction and a nonstick self-lubricating surface. The major disadvantage of UHMW-PE has been wear resulting in particle debris that is not 
biocompatible and can lead to loosening of the prosthesis. Ceramics have poor strength and are brittle. They have been mainly used for filling smaller bony defects. The most popular ceramics have been tri-calcium phosphate and the derived ceramic HA. Tricalcium phosphates are porous ceramics that mimic the microstructure of cancellous bone. Bioglass has a porous structure that supports tissue ingrowth and improves implant-tissue interface and stability. However, it's more suited for load-free areas due to its low fracture resistance..

Synthetic bone substitutes, used as bone 'fillers', are vastly osteoconductive. They carry minimal risk of disease transmission and range from those with minimal osteoinductive capacity (calcium sulphate) to those with high osteoinductive capacity (Bone Morphogenic Proteins (BMP), such as BMP-2 and BMP-7). Calcium sulfate has been implanted as a bony substitute since the $19^{\text {th }}$ century [33]. Current forms of processed calcium sulfate include Osteoset (Wright Medical, Arlington, TN, USA), and Bone Plast (Interpore Cross International, Irvine, CA, USA). Osteoset is indicated for filling small bony defects [51]. Coralline calcium phosphate has a highly organized microstructure, with large interconnected pores that simulate the structure of cancellous bone [51]. Pro-Osteon, a synthetized coralline calcium phosphate converted into hydroxyapatite by heat (Interpore Cross International, Irvine, CA, USA) is available for the treatment of metaphyseal defects [51]. It has a long resorption time, which is one of its initial disadvantages. Vitoss (Orthovita, Malvern, PA, USA) is a $\beta$-tri-calcium phosphate designated for bony defects of the pelvis, extremities, and spine [51]. Vitoss is excessively porous and promotes cell-mediated remodelling and resorption following implantation [51]. It, however, often requires the addition of bone marrow to function properly.

Both synthetic and natural polymers have been extensively investigated. Synthetic degradable polymers, such as polycaprolactone (PCL), polyvinyl alcohol (PVA), and polylactides (PLLA, PLDA), polyorthoester (POE), polyanhydrides, polyglycolide (PGA) and especially poly(lactide-co-glycolide) (PLGA) are most commonly used for bone regeneration [4].

Xenografts are transplantation from another species into humans, such as from bovine [52], porcine, and equine [53] sources. There are also many marine sources (such as coral, algae, cuttlefish, and others) which have also been identified to extract hydroxyapatite and/or calcium carbonate materials and scaffolds [54]. While potentially in high abundance, xenografts have low osteoinductive and osteogenic potential, as well as have the potential to cause crossspecies rejection in some cases [55].

\subsection{Advances in Materials for Bone Tissue Engineering}

Lack of interactions or unsuitable interactions between synthetic materials and tissues remain a major concern; often resulting in implant failure [56 - 59]. When considering biomaterials suitable to support bone tissue engineering, these should stimulate and support both the in-growth of bone as well as remodelling and maturation of bone by providing geometrical cues and suitable stiffness. It is paramount that scaffolds provide sufficient initial mechanical strength to substitute for the loss of the diseased or absent tissue and biodegrade at a rate which is compatible with tissue ingrowth and maturation [4]. No single natural or synthetic compound has similar mechanical properties and bioactivity as bone tissue, which is made of both inorganic and organic components [60]. A common strategy to overcome this issue, and enhance implant biocompatibility has been to modify their surface and microarchitecture with functional moieties and to combine them with other materials to form composites [61 - 65]. A wide range of nano- and micro-scale materials have been utilized in bone tissue engineering, including natural and synthetic polymers [66, 67], ceramics [68 - 70], composites $[27,71,72]$, metals $[73,74]$, and even extracts from coral $[75,76]$ or sponge, coming from either naturallyoccurring (e.g. collagen) or synthetic (e.g. PLGA or PGA) sources [60]. Functional moieties are usually selected to generate biocompatible matrices by carrying specific cues and/or growth factors or non-fouling surfaces, preventing the adherence of undesired proteins and cells.

In addition to improving biocompatibility of implants and bone fillers, several strategies for improving the mechanical properties (compression and flexural) of polymeric scaffolds have been employed including that of synthetic biodegradable polymers. The integration of harder materials into polymeric scaffolds has been investigated for decades [77 - 79]. Noteworthy strategies include the addition of hydroxyapatite and tri-calcium phosphate [80]. The achieved improvement in mechanical properties from such strategies is still in the range of trabecular bone and not comparable to that of cortical bone. Majority of nonmetallic materials have not found widespread use as structural implants owing to inherent deficiencies in mechanical properties,. This has prompted scientists to design and develop mechanically compatible scaffolds that can accommodate the mechanical properties of bone [4, 81], are biocompatible, and induce bone regeneration. 


\section{CARBON NANOSTRUCTURE COMPOSITES}

Over the last 20 years there has been a sharp rise in bone tissue engineering research [1, 4, 60, 66, 82], especially around the use of carbon nanostructures [30, 83 - 85]. Although carbon nanostructures are promising materials for bone tissue engineering for their light weight, strength, conductivity and stability $[72,86]$, they cannot be readily used in their pure form as synthetic bone tissue and have therefore been combined with other materials to create new composites [72, 86]. Consequently, carbon nanostructure-reinforced composites are an emerging class of high-performance materials with unique mechanical properties [41, 42, 64, 65, 72, 78, 87 - 95], having both a high Young's modulus and tensile strength [27, 96 - 105] (Table 2).

Table 2. Physical properties of carbon nanostructures.

\begin{tabular}{|c|c|c|c|}
\hline Structure & $\begin{array}{c}\text { Tensile } \\
\text { Strength (GPa) } \\
\end{array}$ & $\begin{array}{c}\text { Young's } \\
\text { Modulus (GPa) } \\
\end{array}$ & References \\
\hline \multicolumn{4}{|l|}{ Bone } \\
\hline Cortical Bone & $0.051-0.133$ & $12-18$ & {$[27,96,106]$} \\
\hline Cancellous Bone & 0.0074 & $0.1-0.5$ & {$[27,106]$} \\
\hline \multicolumn{4}{|l|}{ Metal Alloys } \\
\hline Stainless Steel & 0.586 & 190 & {$[106]$} \\
\hline Co-Cr alloy & 1.085 & 280 & {$[106]$} \\
\hline Ti-alloy & 0.965 & 116 & {$[106]$} \\
\hline \multicolumn{4}{|l|}{ Ceramics } \\
\hline Alumina & 0.300 & 380 & {$[106]$} \\
\hline Zirconia & 0.820 & 220 & [106] \\
\hline Bioglass & 0.042 & 35 & {$[106]$} \\
\hline Hydroxyappetite & 0.050 & 95 & {$[106]$} \\
\hline \multicolumn{4}{|l|}{ Carbon Nanostructure } \\
\hline Graphene & 130 & 1000 & {$[97,98,107]$} \\
\hline Graphene nanoribbons & $170-175$ & $\sim 1000$ & {$[101,108]$} \\
\hline Graphene oxide nanoplatelets & -- & 220 & {$[97,99,100]$} \\
\hline \multicolumn{4}{|l|}{ Carbon Nanotubes } \\
\hline SWCNT & 126 & $650-5500$ & {$[103,104]$} \\
\hline DWCNT & $23-63$ & -- & {$[116]$} \\
\hline MWCNT & $>63$ & $200-1950$ & {$[103-105]$} \\
\hline Nanodiamonds & $>60$ & $170-1220$ & {$[102,103]$} \\
\hline
\end{tabular}

$\mathrm{Co}=$ cobalt, $\mathrm{Cr}=$ chromium, DWCNT $=$ double-walled carbon nanotubes, MWCNT $=$ multi-walled carbon nanotubes, SWCNT $=$ single-walled carbon nanotubes, $\mathrm{Ti}=$ titanium

\subsection{Carbon Nanostructures}

Graphene, a basic building-block of carbon nanostructures, is a honeycomb lattice of carbon atoms in a single layer. Graphene's planar structure and $\mathrm{sp}^{2}$-hybridized carbon bonds enable it to react in a number of reactions, such as carbine insertion reactions, cyclo-additions, and click reactions [97]. It is one of the thinnest and strongest materials ever examined [107, 110]. Other carbon nano-scale allotropes include multi-walled carbon nanotubes (MWCNT), singlewalled carbon nanotubes (SWCNT), buckyballs, ultra-short single-walled carbon nanotubes (US-SWCNT), graphene nanoribbons, and (graphite) nanoplatelets (Fig. 1), each with their own unique attributes.

Carbon nanotubes (CNTs) are cylinders of rolled-over sheets of graphene, with a typical diameter of a few nanometers and aspect ratios of up to 130000 000:1. Typically, they are insoluble in water, but could be made soluble via chemical modification with single-stranded DNA or phospholipids containing a polyethylene glycol (PEG) moiety, for example. CNTs can be classified into two categories based on their structure: 1) single walled (SWCNTs), which consist of one layer of grapheme cylinder and 2) multi-walled (MWCNTs), which contain multiple layers of graphene cylinders [111]. SWNTs have photoluminescence properties that could be advantageous for applications in imaging and diagnostics, whilst MWNTs provide a larger surface, which could better facilitate external functionalization [112, 113].

Nanodiamonds (NDs), which are diamonds typically measuring 4-10 nanometres in diameter, are different from graphene-based materials as they are $\mathrm{sp}^{3}$ hybridized in a crystal lattice [114] rather than taking on planar architecture of graphene. NDs have excellent protein binding properties and can be carriers of molecules such as BMP-2 and basic 
fibroblast growth factor (b-FGF) [115]. Mochalin et al. provide a broad overview of ND synthesis, purification, deaggregation, surface modifications, properties and applications [116].

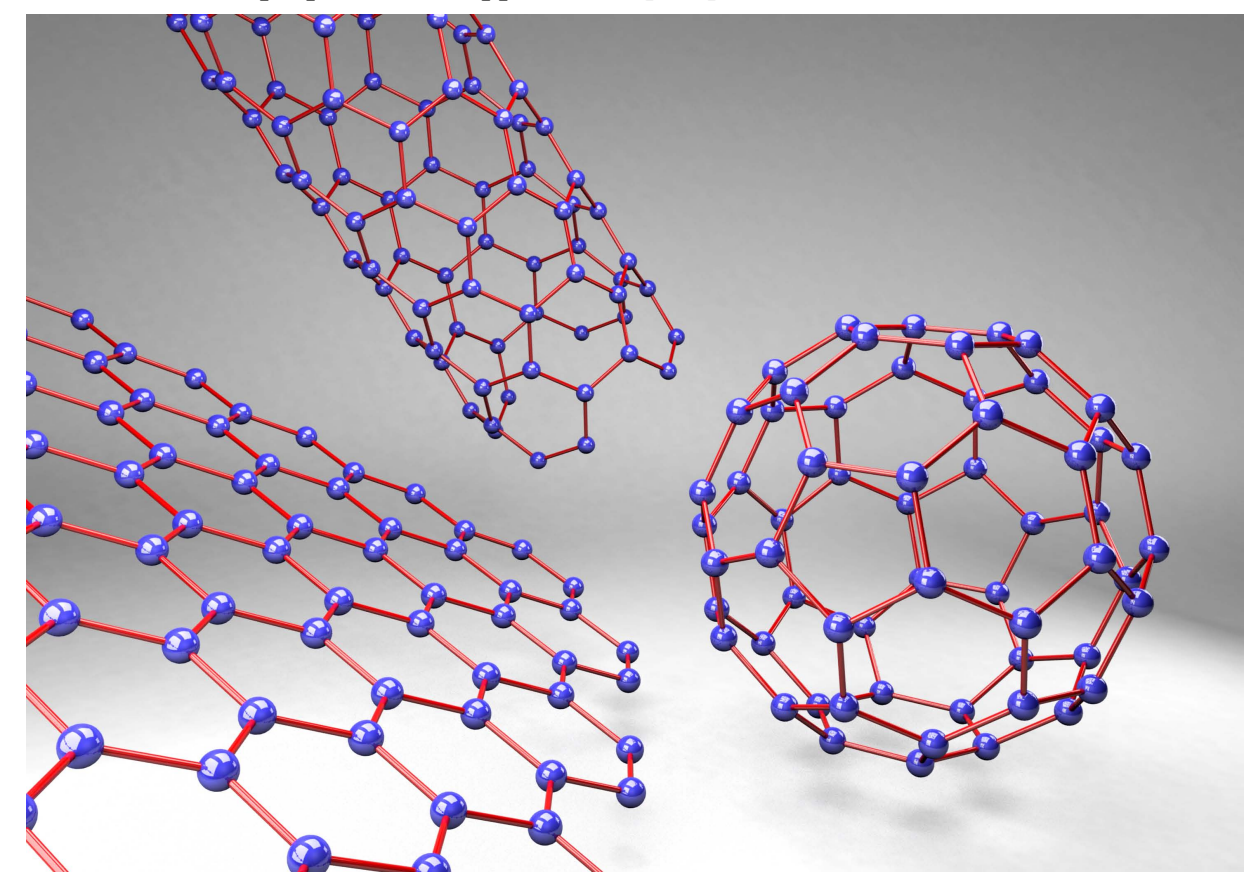

Fig. (1). Carbon Nanostructures Graphene (left), single-walled carbon nanotube (top), buckyball (right).

Pristine carbon nanostructures are incompatible with aqueous solvents and therefore much effort has been made to 'functionalize' these molecules. As such, carbon nanostructures, including graphene, CNTs and NDs, can be functionalized with alkyl, carboxyl, or other groups [117, 118] to improve solubility and dispersion [30]. These functionalizations can affect the carbon nanostructure's physical properties, as well as its osteogenic, osteoconductive and osteoinductive abilities [6, 40, 71, 109, 117, 119 - 121].

\subsection{Carbon Nanostructure-polymer Composites}

The nano-dimensionality of carbon nanostructures offers potentially higher bonding energy and larger surface area. These properties increase the possibility of interfacing with the nanocomposite polymeric scaffold [79, 122]. Many biocompatible polymers, fillers, excipients, and other materials are currently being evaluated for clinical use, not only in bone tissue engineering. Seal [123], Rezwan et al. [27], Middleton et al. [28], and Armentano et al. [29] and others have reviewed some of the most common biodegradable, bioresorbable, bioerodable, and/or bioabsorbable polymers [4, 124], which could potentially be used in conjunction with carbon nanostructures as fillers. Other review articles and individual studies have investigated properties of carbon nanostructure-containing polymeric composites $[64,65,71$, 72, 87, 88, 125, 126]. While Mittal et al. [72] and Venkatesan et al. [30] summarize the properties of CNTs, graphene and polymers, many of the factors they describe can be applied to other carbon nanostructures and scaffolding materials. "Such properties not only depend on the inherent properties of the polymer and the filler, but also on the size and shape of the filler, the distribution of filler within the polymer matrix, and the physical and/or chemical interactions between the polymer and filler" [40].

Graphene and its planar derivatives [e.g. graphene oxide and reduced graphene oxide (nanoplatelets)] have been shown to be an effective filler in polymer composites, and in some instances, outperform CNTs as a filler [72, 127 129]. In some cases, such as with specific polymers, graphene may be the preferential carbon nanostructure of choice. For example, low nanofiller content graphene nanoplatelets performed significantly better than CNTs in terms of enhancing "tensile strength, Young's modulus, fracture toughness, fracture energy, and resistance to fatigue crack growth" [128]. In another instance, MWCNTs were only shown to be effective in epoxy composites when 'unzipped' into graphene nanoplatelets, most likely due to increased surface area and the physical properties of epoxy scaffolding [129].

A wide range of literature reviews and studies exist summarizing the synthesis methods and physical properties of 
polymeric composites containing CNT fillers [43, 71, 72, 77, 79, 83, 85, 92, 109, 130 - 143]. Venkatesan et al. describe scaffolds from chitosan, collagen, gelatin, PCL, PLGA, and PLLA, among others [30]. Most of these composites show clear signs that CNTs enhance the polymers' ability to replace bone tissue. The electrical conductivity of CNTs also brings an interesting element to the use of bone material, as electric stimulation of $10 \mathrm{~mA}$ at $10 \mathrm{~Hz}$ has shown to increase cell proliferation, increase extracellular calcium, and upregulate collogen type-1 [144].

Similar to graphene and CNTs, ND composites are also demonstrating effectiveness in bone tissue scaffolds [145, 146]. Mochoalin and Gogotsi have reviewed the literature for ND-polymer composites, which provides evidence that NDs can improve the properties of the composite, such as the "Young's modulus, hardness, high thermal conductivity and electrical resistivity, low coefficient of friction, chemical stability, and biocompatibility" [146]. Of particular interest are octadecylamine modified ND (ND-ODA), and composites of poly(l-lactic acid) with ND-ODA, which are relatively non-toxic and have "Young's modulus values close to cortical bone" [147]. NDs do not present the same high aspect ratios as CNTs, yet their spherical shape and large surface area per unit of particle volume allow NDs to have a few benefits over CNTs [146].

\subsection{Carbon Nanostructure-ceramic Composites}

Ceramics are of interest to bone tissue engineers due to their high stiffness, high strength, chemical inertness, and low density; but has a lack of toughness and are prone to catastrophic failures if defects exist [148]. The incorporation of carbon nanostructures aims to maintain the materials' strengths, but also increases their toughness, prevents these catastrophic failures from occurring, and increases their functionality as bone tissue. Case in point, ceramics with functionalized graphene have improved physical properties and biological outcomes, such as enhanced osteogenicity (better adhesion of the hMSCs), calcium deposition by osteoblasts, sintering temperature, and electrical conductivity [149 - 151]. Simliarly, graphene nanosheet-HA nanorod (GNS-HA) composites display superior attributes to pristine graphene oxide or hyaluronic acid [152].

There are a range of studies which mix CNTs with ceramic(-like) materials [30] such as hydroxyapatite [153 - 160] and bioglass [69, 70, 151, 161 - 165]. CNTs significantly increase the "compressive strength and fracture toughness (by $106 \%$ and $21 \%$, respectively)" [166] of diopside scaffolds at low concentrations (MWCNTs from 0.5-2 wt \%). "Further, the scaffolds exhibited good apatite-formation ability and supported adhesion and proliferation of cells in vitro" [166].

\subsection{Carbon Nanostructure-polymer-ceramic Composites}

Increasingly, studies are evaluating the effects of polymer-ceramic composites [167 - 169], as well as with carbon nanotubes $[80,87,162,170-172]$. There is still much work to be done as there are an almost limitless number of combinations of carbon nanostructures, polymers and ceramic(-like) compounds which could be mixed together. Early results do look promising. For example, 2-7\% MWCNTs increased the roughness of a poly(3-hydroxybutryate)bioactive glass composite surface, and in low concentrations, enhanced cell attachment and proliferation [162]. Additionally, Chitosan-MWNTs-HA nanocomposites demonstrated a sharp increase in the elastic modulus by $114 \%$ and compressive strength by $218 \%$, by increasing MWNTs-chitosan weight ratios from 0 to $5 \%$ [90]. Plenty more examples of carbon nanostructures enhancing complex composites exist, yet the purpose of this review is not to list all previously evaluated formulations. A more thorough investigation into the literature is required, such as a systematic review of the formulations evaluated and the outcomes of such studies.

\subsection{Effectiveness of Carbon Nanostructures in Bone Tissue}

There are an almost an indefinite combination of carbon nanostructures, polymers, ceramics and other excipients which could be combined to create a potential material for bone tissue repair. Nonetheless, a few promising candidates have been tested both in the in vitro and in vivo settings. While there have been a large number of in vitro experiments evaluating carbon nanostructures, there have not been many which have evaluated carbon nanostructures for bone tissue engineering using in vivo models to date [9]. Nonetheless, carbon nanostructures continue to be some of the most promising materials for bone tissue engineering $[9,30]$.

Dubey et al. have recently summarized a wide range of studies evaluating's graphene's potential to enhance osteogenesis [173]. Newman et al's review thoroughly evaluates studies in the literature from 2002 to 2013 which evaluate the osteogenic and proliferative potential of SWCNT and MWCNT [119], as well as discusses the potentials and pitfalls of CNT design and use. Pristine MWCNTs have been shown to delay the growth of human bone marrow mesenchymal stem cell (hBMSC), however enhance differentiation. Cells "spread on MWCNTs toward a polygonal 
shape", which is an important step in osteogenic differentiation [174]. In addition, hBMSCs preferred MWCNTs to tissue culture plastic for attachment and growth, supporting the osteoinductive properties of MWCNTs [174]. Nanodiamons are also biocompatible [91] and promote osteoblast adhesion and proliferation (osteoconduction and osteogenesis) [175].

SWCNTs and MWCNTs have been shown to be used alone as scaffolding to promote bone cell (osteocytes and osteoblasts) proliferation in vitro [176]. A wide range of studies have shown positive effects of CNT on bone cell proliferation [86, 159, 177 - 183]. In 2002, Supronowicz et al. demonstrated for one of the first times that CNT composites can promote osteoblast functions that are responsible for the organic and inorganic phases of bone composition [144]. Since then, several carbon nanostructure composites, such as carbon nanofiber-polycarbonate urethane (PCU), CNT-poly(lactic acid) (PLA) and CNT-PLGA, were shown to enhance adhesion of osteoblasts in vitro $[83,184-186]$.

Usui et al. have exhibited that MWCNTs implanted into ccy mice "show high bone-tissue compatibility, permit bone repair, become integrated into new bone, and accelerate bone formation stimulated by recombinant human bone morphogenetic protein-2 (rhBMP-2)" [31]. Bhattacharya found that when SWCNT composites were placed in a criticalsized rat calvarial defects, there were few signs of rejection or inflammation and showed adequate bone formation was [187]. Similarly, carbon nanohorns, a type of CNT, have been shown to be both compatible and effective in bone tissue regeneration within rat calvarial bone defects [188]. Likewise, nanodiamonds have also been promising materials in vivo. Addition of oxygen-terminated ND particles to a poly(L-lactide)-co-(e-caprolactone) scaffold significantly increased bone marrow-derived stem cell attachment and proliferation in vivo, along with enhanced bone formation after 24 weeks in vivo [189], which has also been confirmed in vitro [190].

\section{TOXICITY OF CARBON NANOSTRUCTURES}

While carbon nanostructures have been described as "extremely effective and very safe biomaterials" [9] in both in vitro and in vivo testing for bone engineering applications [191], carbon nanostructures present toxicological effects [191 - 201]. This toxicity should be taken into account when engineering synthetic bone tissues. It must also be noted the release of CNTs can occur not only during production, but also during the usage and disposal phases of these applications [202].

The pharmacodynamics, pharmacokinetics, and toxicokinetics of a carbon nanostructure can vary significantly based upon the specific dimensions, surface properties/functionalization, bio-durability and the protein corona surrounding the carbon nanostructure [193, 203]. As the toxicological effects of a carbon nanostructure will most likely differ once combined into a composite, and the fact that many composite materials have been independently tested for safety, we have focused on describing the toxicological effects of common carbon nanostructures below without potential composite materials. Complicating the matter is the fact that studies are difficult to compare due to there being different species, dosing, vehicles, functionalizations, and characterisation techniques; resulting in problematic interpretation and inadequate risk-assessment [192, 204].

\subsection{Biodistribution and Biodurability}

Biodistribution and biodurability of carbon nanostructures is of key concern when developing implants containing these materials. Until this process is understood, their use in the clinic will be obstructed [205]. Pristine CNTs have been found both at the site of exposure as well as other tissues up to 24 months post-administration [206 - 209]. The biodistribution of carbon nanostructures is primarily based upon the allotrope and its chemical functionalization. Pristine (non-functionalized) carbon nanostructures appear to be of most concern in regard to in vivo accumulation. Following intravenous injection, "pristine SWCNTs distributed the entire body with major accumulations in the liver, lungs, and spleen over an extended period of time" [210]. Similarly, when pristine MWCNTs were injected into mice, they "accumulated in the liver, lungs and spleen" [211].

Functionalizations can dramatically change a CNTs pharmacokinetic properties and biodegradability [212]. One study finds that the accumulation of CNTs is ameliorated by the degree of functionalization [213] rather than the functionalization's characteristics (e.g. chemistry or size) [211], however other studies find that degradation rates are functionalization-specific [214]. Ali-Boucetta and Kostarelos suggest functionalization leads to rapid excretion through the bladder-urine route, whereas non-covalently coated CNTs show major accumulation in the liver and spleen [205]. 


\subsection{Cytotoxicity}

Cytotoxicity of carbon nanostructures has been observed along a range of cell lines, concentrations, production methods, excipients and assays [215]. However, recent studies have shown that CNTs have relatively low levels of cytotoxicity and are safe for clinical use [9, 185].

Studies suggest that there are two main mechanisms of carbon nanostructure toxicity: inflammation and reactive oxidative species (ROS), which are inter-related $[192,216]$. Production of ROS results in lipid peroxidation, protein alteration, and intracellular GSH depletion, leading to NF-kB activation which in turn upregulates IL-1 $\beta$, IL-6, TNF- $\alpha$, iNOS (proinflammatory markers) to trigger cell death [216, 217].

Carbon nanostructures have some properties which make them cytotoxic, particularly to immune cells. Carbon nanotubes (CNTs) and fullerenes have been shown to by cytotoxic to alveolar macrophages [199], as well as induce human T-lymphocyte [218] and fibroblast [198] apoptosis in culture. Surface oxidation of CNTs has demonstrated toxicity in vitro, inducing apoptosis in human T lymphocytes [218]. Surface oxidation of CNTs by acidic treatment leads to a dose-dependent cytotoxicity to human neuroblastoma cells [219]. In a mouse model, MWCNTs coated with an acid-based polymer led to higher levels of macrophage-induced inflammation and oxidation [220].

The dimensions, such as length, width, and aspect ratio of a carbon nanostructure can potentially determine its toxicological properties. Murphy et al. demonstrated that for CNTs there is a length-dependant increase in acute cytokine release from THP-1 macrophages, which is most likely due to frustrated phagocytosis [221]. There are conflicting results on whether thinner CNTs appear to be more toxic than thicker CNTs [193, 195, 196, 222], however CNTs with lower aspect ratios demonstrate greater toxicity to human lung-tumor cell lines [223]. Imperfections or defects in carbon nanostructures can also play a role in undesired toxicity. MWCNTs present higher levels of genotoxicity with higher levels of defects [224].

Carboxyl groups have be implicated as a pro-inflammatory functionalization on CNTs [193, 225]. Lanone et al. suggest toxicity could be due to increased bioavailability, negative charge of the functionalization (possibly leading to higher levels of internalisation by macrophages), or both [193]. Conversely, amino [226] and polyethylene glycol (PEG) [216] groups can reduce CNT cytotoxicity, whereas albumin coating can specifically reduce SWCNT toxicity [227]. Furthermore, Wang et al. demonstrated that Pluronic F108 coating decreases (while albumin increases) the lung fibrosis potential of MWCNTs by reducing lysosomal injury [228], suggesting that it is important to consider the excipient used with carbon nanostructures in a composite.

Some experiments have shown that nanodiamonds have little to no cytotoxicity or genotoxicity across a range of tissues [229]. However other studies have detected ND-mediated cytotoxicity, proliferation, inhibition and oxidative stress in HeLa cells, as well as genotoxicity in higher concentrations [230]. Further evaluations are necessary to fully assess the toxicology of nanodiamonds.

\subsection{In Vivo Toxicity}

Acute and sub-chronic mouse and rat studies are summarized by Clichici et al. [192], Lanone [193] and Zhao et al. [215]. They all recommend standardized testing of carbon nanostructures due to the complicated nature of the molecule class and the lack of consistent testing in the literature. Similar to the cytotoxic effects of carbon nanostructures, ROS and inflammation appear to be the main causes of toxicity, leading to inflammation, fibrosis, granulomas and apoptosis [215]. Following implantation of CNTs, a majority of in vivo studies have reported on local reactions [9].

A wide range of inhalation toxicology studies have been performed evaluating CNTs as it is believed that CNTs are generated in the combustion of fuels [231 - 233] as well being an occupational hazard during CNT manufacturing [191, 234]. Lanone et al. [193] describe how the size and dimensions of a (carbon nano-) 'particle' or 'fibre' effects how a nanostructure might react in the lung. Gernand and Casman's meta-analysis of carbon nanotube pulmonary toxicity studies [235] found that the metallic impurities, CNT length and diameter, and aggregate size contribute the most to pulmonary toxicity. A nanoparticle may be more confined to the lungs whereas a nanofibre would have a greater effect on the pleura (e.g. like asbestos). It has been shown in two different mouse models that long MWCNTs "results in asbestos-like, length-dependent, pathogenic behaviour" [236, 237]. Following intrapharyngeal or intratracheal administration of SWCNTs and MWCNTs in mice and rats; "inflammation, epithelioid granulomas (microscopic nodules), fibrosis, and biochemical/toxicological changes in the lungs" [191] were observed, independent of how they were synthesized, or the metal content or type [191, 200, 201]. Furthermore, in a comparative inhalation study in mice, "SWCNTs were more toxic than quartz" [191], a common reference material and known chronic occupational health 
hazard [200, 201]. Although inhalation toxicology may pose a threat to those manufacturing the CNTs or other carbon nanostructures, evidence suggests there should be minimal inhalation exposure while a clinician installs a carbon nanostructure-based composite implant [238].

Further research, methods development and standardization are required to truly evaluate a carbon nanostructure composite's toxicological profile over its life cycle [238], especially once implanted in a patient.

\subsection{Human Exposure Toxicity}

Although they are promising materials, carbon nanostructures for bone tissue engineering are currently in the preclinical stage of development. Huckzo and Lange have evaluated fullerene soot with a high level of SWCNTs was tested to asses topical activity in human volunteers, which resulted in no signs of skin irritation or allergic risk [239]. However, as of October 2015, the authors have not found an evidence of carbon nanostructures being used in randomized clinical trials registered in European Union (clinicaltrialsregister.eu) or United States (clinicaltrials.gov). It is also unclear when these technologies might enter clinical trials for therapeutic purposes.

\section{CONCLUSION}

Carbon nanostructures present an interesting case for bone tissue engineering. They can be used as an additive to currently available materials to form a composite which is osteogenic, osteoconductive and osteoinductive. It is clear that there are a wide range of studies which paint an incomplete, yet informative, picture regarding carbon nanotube functionality and toxicity as a potential filler for bone tissue engineering [192, 205]. Ideally, a composite, whether made from carbon nanostructure(s), polymer(s), and/or ceramic(s), would have to possess all of the biophysicochemical and biomedical properties required of a bone substitute, without exorbitantly increasing the cost to manufacture the goods. Once a composite containing carbon nanostructures is refined and selected, it will require thorough investigations both in vitro and in vivo to ensure efficacy and safety as required by the regulatory agencies. If developing a new composite for clinical application, it would be wise to ensure this formulation was differentiated enough from the intellectual property landscape to allow commercial development of a product through the cost and time required to undertake and complete clinical trials.

While some allotropes of carbon present cytotoxicity and inhalation toxicity in certain instances, carbon nanostructures appear to be safe enough to continue to be evaluated for clinical use. There is evidence that shows that once a carbon nanostructure is fixed into a solid composite form, the effects of carbon nanostructure toxicity can be reduced [90], possibly due to reduced bioavailability, both in particulate form and/or in solution. Toxicokinetic studies suggest that a high level of functionalization of carbon nanostructures might be preferential in vivo. Once a carbon nanostructure detaches from an implant, this high degree of functionalization could prevent bioaccumulation in the liver and spleen. In the case of a long-term implant for bone defects, persistence at 24 months may or may not be beneficial, depending on the level of resorption desired. Based on this potential stability, it may be worthwhile to consider carbon nanocomposites for other uses than only bone defects, such as for joint replacement or full prosthetics.

Currently, the literature is fractured with pockets of combinations for fillers and scaffolding molecules being tested. What is missing from the literature is a systematic evaluation (e.g. factorial experiment/design of experiment) of different carbon nanostructures, polymers, ceramics, cements, bioglasses, fillers and/or excipients in a single evaluation platform. Furthermore, standardized experimental models and desired outcomes (e.g. Young's modulus, elastic strength, HA deposits, etc.) to evaluate engineered bone tissue have not yet reached consensus in the academic community.

Although carbon nanostructures show promise, it must be noted that the high cost of carbon nanostructures has been an obstacle to widespread adoption [21]. The high cost of carbon nanostructures becomes even more exacerbated within regulated biomedical applications, as the cost of cGMP-grade material could be further prohibitive. Just as with DNA sequencing, demand and production of carbon nanostructures will increase. With economies of scale, production costs of carbon nanostructures should (hopefully) reduce significantly to allow further testing and evaluation.

Lastly, other technologies, such as cellular therapies, platelet therapies, growth factors, and other regenerative medicines are being developed in parallel to carbon nanostructures. It is unclear which of the technologies might be the most effective or safe, but it is clear that there is potential for these technologies to be combined synergistically [10, 76, $240-242]$. 


\section{LIST OF ABBREVIATIONS}

\begin{tabular}{|c|c|c|}
\hline b-FGF & $=$ & Basic fibroblast growth factor \\
\hline BMP & $=$ & Bone morphogenic protein \\
\hline cGMP & $=$ & Current good manufacturing practice \\
\hline CNT & $=$ & Carbon nanotubes \\
\hline Co & $=$ & Cobalt \\
\hline $\mathrm{Cr}$ & $=$ & Chromium \\
\hline DBM & $=$ & Demineralized bone matrix \\
\hline DNA & $=$ & Deoxyribonucleic acid \\
\hline DWCNT & $=$ & Double-walled carbon nanotubes \\
\hline GNS-HA & $=$ & Graphene nanosheet-hydroxyapatite \\
\hline GPa & $=$ & Gigapascals \\
\hline GSH & $=$ & Glutathione \\
\hline HA & $=$ & Hydroxyapatite \\
\hline hBMSC & $=$ & Human bone marrow mesenchymal stem cell \\
\hline MWCNT & $=$ & Multi-walled carbon nanotube \\
\hline ND & $=$ & Nanodiamond \\
\hline ND-ODA & $=$ & Octadecylamine modified nanodiamonds \\
\hline nm & $=$ & Nanometers \\
\hline PCL & $=$ & Polycaprolactone \\
\hline PGA & $=$ & Polyglycolide \\
\hline PLDA & $=$ & Poly-D-lactide \\
\hline PLGA & $=$ & Poly(lactide-co-glycolide) \\
\hline PLLA & $=$ & Poly-L-lactide \\
\hline PMMA & $=$ & Polymethylmathacrylate \\
\hline POE & $=$ & Polyorthoester \\
\hline PVA & $=$ & Polyvinyl alcohol \\
\hline ROS & $=$ & Reactive oxidative species \\
\hline SWCNT & $=$ & Single-walled carbon nanotube \\
\hline Ti & $=$ & Titanium \\
\hline UHMWPE & $=$ & Ultra-high molecular weight polyethylene \\
\hline US-SWCNT & $=$ & Ultra-short single-walled carbon nanotube \\
\hline
\end{tabular}

\section{CONFLICT OF INTEREST}

The authors confirm that this article content has no conflict of interest.

\section{ACKNOWLEDGEMENTS}

We would like to thank Steve Atherton MA RMIP MIMI from the medical illustration department of Aberawe Bro Morgannwg University Health Board for generating (Fig. 1).

\section{REFERENCES}

[1] Burg KJ, Porter S, Kellam JF. Biomaterial developments for bone tissue engineering. Biomaterials 2000; 21 (23): $2347-59$. [http://dx.doi.org/10.1016/S0142-9612(00)00102-2] [PMID: 11055282]

[2] Muschler GF, Raut VP, Patterson TE, Wenke JC, Hollinger JO. The design and use of animal models for translational research in bone tissue engineering and regenerative medicine. Tissue Eng Part B Rev 2010; 16(1): 123-45. [http://dx.doi.org/10.1089/ten.teb.2009.0658] [PMID: 19891542]

[3] Grayson WL, Fröhlich M, Yeager K, et al. Engineering anatomically shaped human bone grafts. Proc Natl Acad Sci USA 2010; 107(8): 3299-304 [http://dx.doi.org/10.1073/pnas.0905439106] [PMID: 19820164]

[4] Hutmacher DW. Scaffolds in tissue engineering bone and cartilage. Biomaterials 2000; 21(24): 2529-43. 
[http://dx.doi.org/10.1016/S0142-9612(00)00121-6] [PMID: 11071603]

[5] Warnke PH, Wiltfang J, Springer I, et al. Man as living bioreactor: fate of an exogenously prepared customized tissue-engineered mandible. Biomaterials 2006; 27(17): 3163-7.

[http://dx.doi.org/10.1016/j.biomaterials.2006.01.050] [PMID: 16504287]

[6] Park H, Cannizzaro C, Vunjak-Novakovic G, Langer R, Vacanti CA, Farokhzad OC. Nanofabrication and microfabrication of functional materials for tissue engineering. Tissue Eng 2007; 13(8): 1867-77. [http://dx.doi.org/10.1089/ten.2006.0198] [PMID: 17518744]

[7] Oberdörster G, Maynard A, Donaldson K, et al. ILSI Research Foundation/Risk Science Institute Nanomaterial Toxicity Screening Working Group. Principles for characterizing the potential human health effects from exposure to nanomaterials: elements of a screening strategy. Part Fibre Toxicol 2005; 2(1): 8 .

[http://dx.doi.org/10.1186/1743-8977-2-8] [PMID: 16209704]

[8] Powers KW, Palazuelos M, Moudgil BM, Roberts SM. Characterization of the size, shape, and state of dispersion of nanoparticles for toxicological studies. Nanotoxicology 2007; 1(1): 42-51. [http://dx.doi.org/10.1080/17435390701314902]

[9] Saito N, Haniu H, Usui Y, et al. Safe clinical use of carbon nanotubes as innovative biomaterials. Chem Rev 2014; 114(11): 6040-79. [http://dx.doi.org/10.1021/cr400341h] [PMID: 24720563]

[10] Pryzhkova MV. Concise review: carbon nanotechnology: perspectives in stem cell research. Stem Cells Transl Med 2013; 2(5): 376-83. [http://dx.doi.org/10.5966/sctm.2012-0151] [PMID: 23572053]

[11] Dresselhaus MS, Dresselhaus G, Eklund PC. Science of fullerenes and carbon nanotubes: their properties and applications. New York: Academic press 1996.

[12] Allen MJ, Tung VC, Kaner RB. Honeycomb carbon: a review of graphene. Chem Rev 2010; 110(1): 132-45. [http://dx.doi.org/10.1021/cr900070d] [PMID: 19610631]

[13] Balandin AA. Thermal properties of graphene and nanostructured carbon materials. Nat Mater 2011; 10(8): 569-81. [http://dx.doi.org/10.1038/nmat3064] [PMID: 21778997]

[14] Popov VN. Carbon nanotubes: properties and application. Mater Sci Eng Rep 2004; 43(3): 61-102. [http://dx.doi.org/10.1016/j.mser.2003.10.001]

[15] Perry CR. Bone repair techniques, bone graft, and bone graft substitutes. Clin Orthop Relat Res 1999; (360): 71-86. [http://dx.doi.org/10.1097/00003086-199903000-00010] [PMID: 10101312]

[16] Nandi S, Roy S, Mukherjee P, Kundu B, De DK, Basu D. Orthopaedic applications of bone graft \& graft substitutes: a review. Indian J Med Res 2010; 132: 15-30.

[17] Oryan A, Alidadi S, Moshiri A, Maffulli N. Bone regenerative medicine: classic options, novel strategies, and future directions. J Orthop Surg 2014; 9(1): 18. [http://dx.doi.org/10.1186/1749-799X-9-18] [PMID: 24628910]

[18] Urist MR. Bone: formation by autoinduction. Science 1965; 150(3698): 893-9. [http://dx.doi.org/10.1126/science.150.3698.893] [PMID: 5319761]

[19] Calori GM, Mazza E, Colombo M, Ripamonti C. The use of bone-graft substitutes in large bone defects: any specific needs? Injury 2011; 42(Suppl. 2): S56-63. [http://dx.doi.org/10.1016/j.injury.2011.06.011] [PMID: 21752369]

[20] Giannoudis PV, Einhorn TA, Marsh D. Fracture healing: the diamond concept. Injury 2007; 38(Suppl. 4): S3-6. [http://dx.doi.org/10.1016/S0020-1383(08)70003-2] [PMID: 18224731]

[21] Novoselov KS, Falko VI, Colombo L, Gellert PR, Schwab MG, Kim K. A roadmap for graphene. Nature 2012; 490(7419): 192-200. [http://dx.doi.org/10.1038/nature11458] [PMID: 23060189]

[22] Greenwald AS, Boden SD, Goldberg VM, Khan Y, Laurencin CT, Rosier RN. American Academy of Orthopaedic Surgeons. The Committee on Biological Implants. Bone-graft substitutes: facts, fictions, and applications. J Bone Joint Surg Am 2001; 83-A(2)(Suppl. 2 Pt 2): $98-103$. [http://dx.doi.org/10.2106/00004623-200100022-00007] [PMID: 11712842]

[23] Carvalho RS, Einhorn TA, Lehmann W, et al. The role of angiogenesis in a murine tibial model of distraction osteogenesis. Bone 2004; 34(5): 849-61. [http://dx.doi.org/10.1016/j.bone.2003.12.027] [PMID: 15121017]

[24] Van Strijen PJ, Breuning KH, Becking AG, Perdijk FB, Tuinzing DB. Cost, operation and hospitalization times in distraction osteogenesis versus sagittal split osteotomy. J Craniomaxillofac Surg 2003; 31(1): 42-5. [http://dx.doi.org/10.1016/S1010-5182(02)00161-0] [PMID: 12553926]

[25] Figueroa AA, Polley JW. Management of severe cleft maxillary deficiency with distraction osteogenesis: procedure and results. Am J Orthod Dentofacial Orthop 1999; 115(1): 1-12. [http://dx.doi.org/10.1016/S0889-5406(99)70310-0] [PMID: 9878952]

[26] Hidding J, Lazar F, Zöller JE. Initial outcome of vertical distraction osteogenesis of the atrophic alveolar ridge. Mund Kiefer Gesichtschir 1999; 3(Suppl. 1): S79-83. 
[http://dx.doi.org/10.1007/PL00014524] [PMID: 10414089]

[27] Rezwan K, Chen QZ, Blaker JJ, Boccaccini AR. Biodegradable and bioactive porous polymer/inorganic composite scaffolds for bone tissue engineering. Biomaterials 2006; 27(18): 3413-31.

[http://dx.doi.org/10.1016/j.biomaterials.2006.01.039] [PMID: 16504284]

[28] Middleton JC, Tipton AJ. Synthetic biodegradable polymers as orthopedic devices. Biomaterials 2000; 21(23): 2335-46. [http://dx.doi.org/10.1016/S0142-9612(00)00101-0] [PMID: 11055281]

[29] Armentano I, Dottoria M, Fortunatia E, Mattiolia S, Kennya JM. Biodegradable polymer matrix nanocomposites for tissue engineering: A review. Polym Degrad Stabil 2010; 95(11): 2126-46.

[http://dx.doi.org/10.1016/j.polymdegradstab.2010.06.007]

[30] Venkatesan J, Pallela R, Kim S-K. Applications of carbon nanomaterials in bone tissue engineering. J Biomed Nanotechnol 2014; 10(10): 3105-23.

[http://dx.doi.org/10.1166/jbn.2014.1969] [PMID: 25992431]

[31] Usui Y, Aoki K, Narita N, et al. Carbon nanotubes with high bone-tissue compatibility and bone-formation acceleration effects. Small 2008; 4(2): 240-6.

[http://dx.doi.org/10.1002/smll.200700670] [PMID: 18205152]

[32] Bauer TW, Muschler GF. Bone graft materials. An overview of the basic science. Clin Orthop Relat Res 2000; (371): 10-27. [http://dx.doi.org/10.1097/00003086-200002000-00003] [PMID: 10693546]

[33] Keating JF, McQueen MM. Substitutes for autologous bone graft in orthopaedic trauma. J Bone Joint Surg Br 2001; 83(1): 3-8. [http://dx.doi.org/10.1302/0301-620X.83B1.11952] [PMID: 11245534]

[34] Fischer CR, Cassilly R, Cantor W, Edusei E, Hammouri Q, Errico T. A systematic review of comparative studies on bone graft alternatives for common spine fusion procedures. Eur Spine J 2013; 22(6): 1423-35. [http://dx.doi.org/10.1007/s00586-013-2718-4] [PMID: 23440339]

[35] Fujiki M, Miyamoto S, Sakuraba M, Nagamatsu S, Hayashi R. A comparison of perioperative complications following transfer of fibular and scapular flaps for immediate mandibular reconstruction. J Plast Reconstr Aesthet Surg 2013; 66(3): 372-5. [http://dx.doi.org/10.1016/j.bjps.2012.10.003] [PMID: 23102764]

[36] Polyzois D, Papachristou G, Kotsiopoulos K, Plessas S. Treatment of tibial and femoral bone loss by distraction osteogenesis. Experience in 28 infected and 14 clean cases. Acta Orthop Scand Suppl 1997; 275: 84-8. [http://dx.doi.org/10.1080/17453674.1997.11744753] [PMID: 9385275]

[37] Griffith LG, Naughton G. Tissue engineeringcurrent challenges and expanding opportunities. Science 2002; 295(5557): 1009-14. [http://dx.doi.org/10.1126/science.1069210] [PMID: 11834815]

[38] Anselme K. Osteoblast adhesion on biomaterials. Biomaterials 2000; 21(7): 667-81. [http://dx.doi.org/10.1016/S0142-9612(99)00242-2] [PMID: 10711964]

[39] Hench LL. Biomaterials: a forecast for the future. Biomaterials 1998; 19(16): 1419-23. [http://dx.doi.org/10.1016/S0142-9612(98)00133-1] [PMID: 9794512]

[40] Mikael PE, Amini AR, Basu J, et al. Functionalized carbon nanotube reinforced scaffolds for bone regenerative engineering: fabrication, in vitro and in vivo evaluation. Biomed Mater 2014; 9(3): 035001. [http://dx.doi.org/10.1088/1748-6041/9/3/035001] [PMID: 24687391]

[41] Li J-L, Yang Z, Loo WTY, et al. In vitro and in vivo biocompatibility of multi-walled carbon nanotube/biodegradable polymer nanocomposite for bone defects repair. J Bioact Compat Polym 2014; 29(4): 350-67. [http://dx.doi.org/10.1177/0883911514533867]

[42] Gupta A, Main BJ, Taylor BL, et al. In vitro evaluation of three-dimensional single-walled carbon nanotube composites for bone tissue engineering. J Biomed Mater Res A 2014; 102(11): 4118-26.

[http://dx.doi.org/10.1002/jbm.a.35088] [PMID: 24443220]

[43] Sahithi K, Swetha M, Ramasamy K, Srinivasan N, Selvamurugan N. Polymeric composites containing carbon nanotubes for bone tissue engineering. Int J Biol Macromol 2010; 46(3): 281-3. [http://dx.doi.org/10.1016/j.ijbiomac.2010.01.006] [PMID: 20093139]

[44] Albrektsson T, Johansson C. Osteoinduction, osteoconduction and osseointegration. Eur Spine J 2001; 10(2)(Suppl. 2): S96-S101. [PMID: 11716023]

[45] Engh CA, Bobyn JD, Glassman AH. Porous-coated hip replacement. The factors governing bone ingrowth, stress shielding, and clinical results. J Bone Joint Surg Br 1987; 69(1): 45-55. [PMID: 3818732]

[46] Huiskes R, Weinans H, van Rietbergen B. The relationship between stress shielding and bone resorption around total hip stems and the effects of flexible materials. Clin Orthop Relat Res 1992; (274): 124-34. [PMID: 1728998]

[47] Bugbee WD, Culpepper WJ II, Engh CA Jr, Engh CA Sr. Long-term clinical consequences of stress-shielding after total hip arthroplasty without cement. J Bone Joint Surg Am 1997; 79(7): 1007-12. [http://dx.doi.org/10.2106/00004623-199707000-00006] [PMID: 9234876] 
[48] Gamradt SC, Lieberman JR. Bone graft for revision hip arthroplasty: biology and future applications. Clin Orthop Relat Res 2003; (417): 183-94. [PMID: 14646716]

[49] Urist MR, Dawson E. Intertransverse process fusion with the aid of chemosterilized autolyzed antigen-extracted allogeneic (AAA) bone. Clin Orthop Relat Res 1981; (154): 97-113. [PMID: 7009018]

[50] Bostrom MP, Camacho NP. Potential role of bone morphogenetic proteins in fracture healing. Clin Orthop Relat Res 1998; (355): (Suppl.)S274-82. [http://dx.doi.org/10.1097/00003086-199810001-00028] [PMID: 9917647]

[51] Bucholz RW. Nonallograft osteoconductive bone graft substitutes. Clin Orthop Relat Res 2002; (395): $44-52$. [http://dx.doi.org/10.1097/00003086-200202000-00006] [PMID: 11937865]

[52] Bansal MR, Bhagat SB, Shukla DD. Bovine cancellous xenograft in the treatment of tibial plateau fractures in elderly patients. Int Orthop 2009; 33(3): 779-84. [http://dx.doi.org/10.1007/s00264-008-0526-y] [PMID: 18365191]

[53] Tetè S, Zizzari VL, Vinci R, et al. Equine and porcine bone substitutes in maxillary sinus augmentation: a histological and immunohistochemical analysis of VEGF expression. J Craniofac Surg 2014; 25(3): 835-9. [http://dx.doi.org/10.1097/SCS.0000000000000679] [PMID: 24820710]

[54] Clarke SA, Walsh P, Maggs CA, Buchanan F. Designs from the deep: marine organisms for bone tissue engineering. Biotechnol Adv 2011; 29(6): 610-7.

[http://dx.doi.org/10.1016/j.biotechadv.2011.04.003] [PMID: 21527337]

[55] Dalmasso AP, Vercellotti GM, Platt JL, Bach FH. Inhibition of complement-mediated endothelial cell cytotoxicity by decay-accelerating factor. Potential for prevention of xenograft hyperacute rejection. Transplantation 1991; 52(3): 530-3. [http://dx.doi.org/10.1097/00007890-199109000-00029] [PMID: 1716798]

[56] Tang L, Eaton JW. Inflammatory responses to biomaterials. Am J Clin Pathol 1995; 103(4): 466-71. [http://dx.doi.org/10.1093/ajcp/103.4.466] [PMID: 7726145]

[57] Brodbeck WG, Shive MS, Colton E, Nakayama Y, Matsuda T, Anderson JM. Influence of biomaterial surface chemistry on the apoptosis of adherent cells. J Biomed Mater Res 2001; 55(4): 661-8. [http://dx.doi.org/10.1002/1097-4636(20010615)55:4<661::AID-JBM1061>3.0.CO;2-F] [PMID: 11288096]

[58] Hubbell JA. Biomaterials in tissue engineering. Biotechnology (NY) 1995; 13(6): 565-76. [http://dx.doi.org/10.1038/nbt0695-565] [PMID: 9634795]

[59] Williams DF. On the mechanisms of biocompatibility. Biomaterials 2008; 29(20): 2941-53. [http://dx.doi.org/10.1016/j.biomaterials.2008.04.023] [PMID: 18440630]

[60] Shrivats AR, McDermott MC, Hollinger JO. Bone tissue engineering: state of the union. Drug Discov Today 2014; 19(6): 781-6. [http://dx.doi.org/10.1016/j.drudis.2014.04.010] [PMID: 24768619]

[61] Chesnutt BM, Viano AM, Yuan Y, et al. Design and characterization of a novel chitosan/nanocrystalline calcium phosphate composite scaffold for bone regeneration. J Biomed Mater Res A 2009; 88(2): 491-502. [http://dx.doi.org/10.1002/jbm.a.31878] [PMID: 18306307]

[62] Hennessy KM, Pollot BE, Clem WC, et al. The effect of collagen I mimetic peptides on mesenchymal stem cell adhesion and differentiation, and on bone formation at hydroxyapatite surfaces. Biomaterials 2009; 30(10): 1898-909. [http://dx.doi.org/10.1016/j.biomaterials.2008.12.053] [PMID: 19157536]

[63] Cao H, Kuboyama N. A biodegradable porous composite scaffold of PGA/ $\beta$-TCP for bone tissue engineering. Bone 2010; $46(2)$ : 386-95. [http://dx.doi.org/10.1016/j.bone.2009.09.031] [PMID: 19800045]

[64] Cheng Q, Rutledge K, Jabbarzadeh E. Carbon nanotube-poly(lactide-co-glycolide) composite scaffolds for bone tissue engineering applications. Ann Biomed Eng 2013; 41(5): 904-16.

[http://dx.doi.org/10.1007/s10439-012-0728-8] [PMID: 23283475]

[65] Wang W, Liao S, Liu M, Zhao Q, Zhu Y. Polymer composites reinforced by nanotubes as scaffolds for tissue engineering. Int J Polym Sci 2014; 2014: 1-14.

[66] Liu X, Ma PX. Polymeric scaffolds for bone tissue engineering. Ann Biomed Eng 2004; 32(3): 477-86. [http://dx.doi.org/10.1023/B:ABME.0000017544.36001.8e] [PMID: 15095822]

[67] Pham QP, Sharma U, Mikos AG. Electrospinning of polymeric nanofibers for tissue engineering applications: a review. Tissue Eng 2006; 12(5): 1197-211.

[http://dx.doi.org/10.1089/ten.2006.12.1197] [PMID: 16771634]

[68] Seitz H, Rieder W, Irsen S, Leukers B, Tille C. Three-dimensional printing of porous ceramic scaffolds for bone tissue engineering. J Biomed Mater Res B Appl Biomater 2005; 74(2): 782-8. [http://dx.doi.org/10.1002/jbm.b.30291] [PMID: 15981173]

[69] Chen QZ, Thompson ID, Boccaccini AR. 45S5 Bioglass-derived glass-ceramic scaffolds for bone tissue engineering. Biomaterials 2006; 
27(11): 2414-25.

[http://dx.doi.org/10.1016/j.biomaterials.2005.11.025] [PMID: 16336997]

[70] Gerhardt L-C, Boccaccini AR. Bioactive glass and glass-ceramic scaffolds for bone tissue engineering. Materials (Basel) 2010; 3(7): 3867-910. [http://dx.doi.org/10.3390/ma3073867]

[71] Ma P-C, Siddiqui NA, Marom G, Kim J-K. Dispersion and functionalization of carbon nanotubes for polymer-based nanocomposites: a review. Compos, Part A Appl Sci Manuf 2010; 41(10): 1345-67. [http://dx.doi.org/10.1016/j.compositesa.2010.07.003]

[72] Mittal G, Dhand V, Rhee KY, Park S-J, Lee WR. A review on carbon nanotubes and graphene as fillers in reinforced polymer nanocomposites. J Ind Eng Chem 2015; 21: 11-25. [http://dx.doi.org/10.1016/j.jiec.2014.03.022]

[73] Wen C, Yamada Y, Shimojima K, Chino Y, Hosokawa H, Mabuchi M. Novel titanium foam for bone tissue engineering. J Mater Res 2002; 17(10): 2633-9. [http://dx.doi.org/10.1557/JMR.2002.0382]

[74] Bose S, Roy M, Bandyopadhyay A. Recent advances in bone tissue engineering scaffolds. Trends Biotechnol 2012; 30(10): 546-54. [http://dx.doi.org/10.1016/j.tibtech.2012.07.005] [PMID: 22939815]

[75] Day AG, Francis WR, Fu K. Assessment of osteogenic potential of injectable human mesenchymal stem cells/coralline hydroxyapatite/calcium carbonate microtissues. Eur Cell Mater 2014; 28(5): 10.

[76] Liu G, Zhang Y, Liu B, Sun J, Li W, Cui L. Bone regeneration in a canine cranial model using allogeneic adipose derived stem cells and coral scaffold. Biomaterials 2013; 34(11): 2655-64. [http://dx.doi.org/10.1016/j.biomaterials.2013.01.004] [PMID: 23343633]

[77] Bal S, Samal SS. Carbon nanotube reinforced polymer composites-a state of the art. Bull Mater Sci 2007; 30: 379-86. [http://dx.doi.org/10.1007/s12034-007-0061-2]

[78] Fan H, Wang L, Zhao K, et al. Fabrication, mechanical properties, and biocompatibility of graphene-reinforced chitosan composites Biomacromolecules 2010; 11(9): 2345-51. [http://dx.doi.org/10.1021/bm100470q] [PMID: 20687549]

[79] Li X, Gao H, Scrivens WA, et al. Reinforcing mechanisms of single-walled carbon nanotube-reinforced polymer composites. J Nanosci Nanotechnol 2007; 7(7): 2309-17.

[http://dx.doi.org/10.1166/jnn.2007.410] [PMID: 17663245]

[80] Liu H, Webster TJ. Mechanical properties of dispersed ceramic nanoparticles in polymer composites for orthopedic applications. Int J Nanomedicine 2010; 5: 299-313. [PMID: 20463945]

[81] Amini AR, Laurencin CT, Nukavarapu SP. Bone tissue engineering: recent advances and challenges. Crit Rev Biomed Eng 2012; 40(5): $363-408$.

[http://dx.doi.org/10.1615/CritRevBiomedEng.v40.i5.10] [PMID: 23339648]

[82] Venkatesan J, Kim SK. Carbon Nanotube for Bone Repair. Handbook of Polymer Nanocomposites. Processing, Performance and Application. Berlin Heidelberg: Springer-Verlag 2015; pp. 511-26. [http://dx.doi.org/10.1007/978-3-642-45229-1_40]

[83] Shi X, Hudson JL, Spicer PP, Tour JM, Krishnamoorti R, Mikos AG. Injectable nanocomposites of single-walled carbon nanotubes and biodegradable polymers for bone tissue engineering. Biomacromolecules 2006; 7(7): 2237-42. [http://dx.doi.org/10.1021/bm060391v] [PMID: 16827593]

[84] Shi X, Sitharaman B, Pham QP, et al. Fabrication of porous ultra-short single-walled carbon nanotube nanocomposite scaffolds for bone tissue engineering. Biomaterials 2007; 28(28): 4078-90. [http://dx.doi.org/10.1016/j.biomaterials.2007.05.033] [PMID: 17576009]

[85] Sitharaman B, Shi X, Walboomers XF, et al. In vivo biocompatibility of ultra-short single-walled carbon nanotube/biodegradable polymer nanocomposites for bone tissue engineering. Bone 2008; 43(2): 362-70. [http://dx.doi.org/10.1016/j.bone.2008.04.013] [PMID: 18541467]

[86] Nayak TR, Jian L, Phua LC, Ho HK, Ren Y, Pastorin G. Thin films of functionalized multiwalled carbon nanotubes as suitable scaffold materials for stem cells proliferation and bone formation. ACS Nano 2010; 4(12): 7717-25. [http://dx.doi.org/10.1021/nn102738c] [PMID: 21117641]

[87] Liao CZ, Li K, Wong HM, Tong WY, Yeung KW, Tjong SC. Novel polypropylene biocomposites reinforced with carbon nanotubes and hydroxyapatite nanorods for bone replacements. Mater Sci Eng C Mater Biol Appl 2013; 33(3): 1380-8. [http://dx.doi.org/10.1016/j.msec.2012.12.039] [PMID: 23827585]

[88] Lalwani G, Henslee AM, Farshid B, et al. Two-dimensional nanostructure-reinforced biodegradable polymeric nanocomposites for bone tissue engineering. Biomacromolecules 2013; 14(3): 900-9. [http://dx.doi.org/10.1021/bm301995s] [PMID: 23405887]

[89] Dervishi E, Hategekimana F, Boyer L, et al. The effect of carbon nanotubes and graphene on the mechanical properties of multi-component 
polymeric composites. Chem Phys Lett 2013; 590: 126-30.

[http://dx.doi.org/10.1016/j.cplett.2013.10.060]

[90] Chen L, Hu J, Shen X, Tong H. Synthesis and characterization of chitosan-multiwalled carbon nanotubes/hydroxyapatite nanocomposites for bone tissue engineering. J Mater Sci Mater Med 2013; 24(8): 1843-51. [http://dx.doi.org/10.1007/s10856-013-4954-x] [PMID: 23712535]

[91] Zhang Q, Mochalin VN, Neitzel I, et al. Mechanical properties and biomineralization of multifunctional nanodiamond-PLLA composites for bone tissue engineering. Biomaterials 2012; 33(20): 5067-75. [http://dx.doi.org/10.1016/j.biomaterials.2012.03.063] [PMID: 22494891]

[92] Roy N, Sengupta R, Bhowmick AK. Modifications of carbon for polymer composites and nanocomposites. Prog Polym Sci 2012; 37(6): 781-819.

[http://dx.doi.org/10.1016/j.progpolymsci.2012.02.002]

[93] Pan L, Pei X, He R, Wan Q, Wang J. Multiwall carbon nanotubes/polycaprolactone composites for bone tissue engineering application. Colloids Surf B Biointerfaces 2012; 93: 226-34. [http://dx.doi.org/10.1016/j.colsurfb.2012.01.011] [PMID: 22305638]

[94] Verdejo R, Jell G, Safinia L, Bismarck A, Stevens MM, Shaffer MS. Reactive polyurethane carbon nanotube foams and their interactions with osteoblasts. J Biomed Mater Res A 2009; 88(1): 65-73. [http://dx.doi.org/10.1002/jbm.a.31698] [PMID: 18260133]

[95] Harrison BS, Atala A. Carbon nanotube applications for tissue engineering. Biomaterials 2007; 28(2): $344-53$. [http://dx.doi.org/10.1016/j.biomaterials.2006.07.044] [PMID: 16934866]

[96] Turner CH, Wang T, Burr DB. Shear strength and fatigue properties of human cortical bone determined from pure shear tests. Calcif Tissue Int 2001; 69(6): 373-8.

[http://dx.doi.org/10.1007/s00223-001-1006-1] [PMID: 11800235]

[97] Goenka S, Sant V, Sant S. Graphene-based nanomaterials for drug delivery and tissue engineering. J Control Release 2014; 173 : 75-88. [http://dx.doi.org/10.1016/j.jconrel.2013.10.017] [PMID: 24161530]

[98] Li J-L, Kudin KN, McAllister MJ, Prudhomme RK, Aksay IA, Car R. Oxygen-driven unzipping of graphitic materials. Phys Rev Lett 2006; 96(17): 176101. [http://dx.doi.org/10.1103/PhysRevLett.96.176101] [PMID: 16712313]

[99] Suk JW, Piner RD, An J, Ruoff RS. Mechanical properties of monolayer graphene oxide. ACS Nano 2010; 4(11): $6557-64$. [http://dx.doi.org/10.1021/nn101781v] [PMID: 20942443]

[100] Dikin DA, Stankovich S, Zimney EJ, et al. Preparation and characterization of graphene oxide paper. Nature 2007; 448(7152): 457-60. [http://dx.doi.org/10.1038/nature06016] [PMID: 17653188]

[101] Bu H, Chen Y, Zou M, Yi H, Bi K, Ni Z. Atomistic simulations of mechanical properties of graphene nanoribbons. Phys Lett A 2009; 373(37): 3359-62. [http://dx.doi.org/10.1016/j.physleta.2009.07.048]

[102] Ekimov E, Gromnitskaya EL, Gierlotka S, et al. Mechanical behavior and microstructure of nanodiamond-based composite materials. J Mater Sci Lett 2002; 21(21): 1699-702 [http://dx.doi.org/10.1023/A:1020889129195]

[103] Fredriksson T. Carbon Nanotubes: A Theoretical study of Young's modulus, Thesis. Karlstad University 2014 ; p. 63.

[104] Yu M-F, Files BS, Arepalli S, Ruoff RS. Tensile loading of ropes of single wall carbon nanotubes and their mechanical properties. Phys Rev Lett 2000; 84(24): 5552-5. [http://dx.doi.org/10.1103/PhysRevLett.84.5552] [PMID: 10990992]

[105] Yu M-F, Lourie O, Dyer MJ, Moloni K, Kelly TF, Ruoff RS. Strength and breaking mechanism of multiwalled carbon nanotubes under tensile load. Science 2000; 287(5453): 637-40. [http://dx.doi.org/10.1126/science.287.5453.637] [PMID: 10649994]

[106] Hench L, Kokubo T. Properties of bioactive glasses and glass ceramics. In: Black J, Hastings G, Eds. Handbook of biomaterials properties. 1998.

[107] Lee C, Wei X, Kysar JW, Hone J. Measurement of the elastic properties and intrinsic strength of monolayer graphene. Science 2008; 321(5887): 385-8 [http://dx.doi.org/10.1126/science.1157996] [PMID: 18635798]

[108] Orlov A, Ovid'ko I. Mechanical properties of graphene nanoribbons: a selective review of computer simulations. Rev Adv Mater Sci 2015; 40: $249-56$.

[109] Sahoo NG, Rana S, Cho JW, Li L, Chan SH. Polymer nanocomposites based on functionalized carbon nanotubes. Prog Polym Sci 2010; 35(7): 837-67.

[http://dx.doi.org/10.1016/j.progpolymsci.2010.03.002]

[110] Geim AK. Graphene: status and prospects. Science 2009; 324(5934): 1530-4. [http://dx.doi.org/10.1126/science.1158877] [PMID: 19541989] 
[111] Sinha N, Yeow JT. Carbon nanotubes for biomedical applications. IEEE Trans Nanobioscience 2005; 4(2): 180-95. [http://dx.doi.org/10.1109/TNB.2005.850478] [PMID: 16117026]

[112] Bachilo SM, Strano MS, Kittrell C, Hauge RH, Smalley RE, Weisman RB. Structure-assigned optical spectra of single-walled carbon nanotubes. Science 2002; 298(5602): 2361-6.

[http://dx.doi.org/10.1126/science.1078727] [PMID: 12459549]

[113] Li N, Yuan R, Chai Y, Chen S, An H. Sensitive immunoassay of human chorionic gonadotrophin based on multi-walled carbon nanotubechitosan matrix. Bioprocess Biosyst Eng 2008; 31(6): 551-8. [http://dx.doi.org/10.1007/s00449-008-0201-0] [PMID: 18324418]

[114] Hopley EL, Salmasi S, Kalaskar DM, Seifalian AM. Carbon nanotubes leading the way forward in new generation 3D tissue engineering. Biotechnol Adv 2014; 32(5): 1000-14.

[http://dx.doi.org/10.1016/j.biotechadv.2014.05.003] [PMID: 24858314]

[115] Moore L, Gatica M, Kim H, Osawa E, Ho D. Multi-protein delivery by nanodiamonds promotes bone formation. J Dent Res 2013; 92(11): 976-81. [http://dx.doi.org/10.1177/0022034513504952] [PMID: 24045646]

[116] Mochalin VN, Shenderova O, Ho D, Gogotsi Y. The properties and applications of nanodiamonds. Nat Nanotechnol 2011; 7(1): 11-23. [http://dx.doi.org/10.1038/nnano.2011.209] [PMID: 22179567]

[117] Chen S, Shen W, Wu G, Chen D, Jiang M. A new approach to the functionalization of single-walled carbon nanotubes with both alkyl and carboxyl groups. Chem Phys Lett 2005; 402(4): 312-7. [http://dx.doi.org/10.1016/j.cplett.2004.12.035]

[118] Madani SY, Naderi N, Dissanayake O, Tan A, Seifalian AM. A new era of cancer treatment: carbon nanotubes as drug delivery tools. Int J Nanomedicine 2011; 6: 2963-79. [PMID: 22162655]

[119] Newman P, Minett A, Ellis-Behnke R, Zreiqat H. Carbon nanotubes: their potential and pitfalls for bone tissue regeneration and engineering. Nanomedicine (Lond) 2013; 9(8): 1139-58. [PMID: 23770067]

[120] Przekora A, Benko A, Nocun M, Wyrwa J, Blazewicz M, Ginalska G. Titanium coated with functionalized carbon nanotubesa promising novel material for biomedical application as an implantable orthopaedic electronic device. Mater Sci Eng C Mater Biol Appl 2014; 45: 287-96.

[http://dx.doi.org/10.1016/j.msec.2014.09.025] [PMID: 25491831]

[121] Zhang Y, Bai Y, Yan B. Functionalized carbon nanotubes for potential medicinal applications. Drug Discov Today 2010; 15 (11-12): 428-35. [http://dx.doi.org/10.1016/j.drudis.2010.04.005] [PMID: 20451656]

[122] Ajayan PM, Tour JM. Materials science: nanotube composites. Nature 2007; 447(7148): 1066-8. [http://dx.doi.org/10.1038/4471066a] [PMID: 17597753]

[123] Seal B, Otero T, Panitch A. Polymeric biomaterials for tissue and organ regeneration. Mater Sci Eng Rep 2001; 34(4): 147-230. [http://dx.doi.org/10.1016/S0927-796X(01)00035-3]

[124] Vert M, Li SM, Spenlehauer G, Guerin P. Bioresorbability and biocompatibility of aliphatic polyesters. J Mater Sci Mater Med 1992; 3(6): 432-46. [http://dx.doi.org/10.1007/BF00701240]

[125] Kumar JS, Baskaran D, Kumar S. Application of carbon nano tubes in bone regeneration-a review. J Nanosci Nanotechnol 2014; 2(1): 246-52.

[126] Rafiee R, Moghadam RM. On the modeling of carbon nanotubes: a critical review. Compos Part B Eng 2014; 56: 435-49. [http://dx.doi.org/10.1016/j.compositesb.2013.08.037]

[127] Zhao X, Zhang Q, Chen D. Enhanced mechanical properties of graphene-based poly (vinyl alcohol) composites. Macromolecules 2010; 43(5): 2357-63.

[http://dx.doi.org/10.1021/ma902862u]

[128] Rafiee MA, Rafiee J, Wang Z, Song H, Yu ZZ, Koratkar N. Enhanced mechanical properties of nanocomposites at low graphene content. ACS Nano 2009; 3(12): 3884-90. [http://dx.doi.org/10.1021/nn9010472] [PMID: 19957928]

[129] Rafiee MA, Lu W, Thomas AV, et al. Graphene nanoribbon composites. ACS Nano 2010; 4(12): 7415-20 [http://dx.doi.org/10.1021/nn102529n] [PMID: 21080652]

[130] Andrews R, Weisenberger MC. Carbon nanotube polymer composites. Curr Opin Solid State Mater Sci 2004; 8: 31-7. [http://dx.doi.org/10.1016/j.cossms.2003.10.006]

[131] Desai AV, Haque MA. Mechanics of the interface for carbon nanotube-polymer composites. Thin Walled Struct 2005; 43: 1787-803. [http://dx.doi.org/10.1016/j.tws.2005.07.003]

[132] Spitalsky Z, Tasis D, Papagelis K, Galiotis C. Carbon nanotube-polymer composites: chemistry, processing, mechanical and electrical properties. Prog Polym Sci 2010; 35(3): 357-401. 
[http://dx.doi.org/10.1016/j.progpolymsci.2009.09.003]

[133] Fitzer E, Manocha LM. Carbon reinforcements and carbon/carbon composites. Berlin: Springer Science \& Business Media 2012.

[134] Han Z, Fina A. Thermal conductivity of carbon nanotubes and their polymer nanocomposites: a review. Prog Polym Sci 2011; 36(7): 914-44. [http://dx.doi.org/10.1016/j.progpolymsci.2010.11.004]

[135] Kim SW, Kim T, Kim YS, et al. Surface modifications for the effective dispersion of carbon nanotubes in solvents and polymers. Carbon 2012; 50(1): 3-33.

[http://dx.doi.org/10.1016/j.carbon.2011.08.011]

[136] Savage E. Carbon-carbon composites. Berlin: Springer Science \& Business Media 2012.

[137] Andrews R, Weisenberger M. Carbon nanotube polymer composites. Curr Opin Solid State Mater Sci 2004; 8(1): 31-7. [http://dx.doi.org/10.1016/j.cossms.2003.10.006]

[138] Kedem S, Schmidt J, Paz Y, Cohen Y. Composite polymer nanofibers with carbon nanotubes and titanium dioxide particles. Langmuir 2005; 21(12): 5600-4. [http://dx.doi.org/10.1021/la0502443] [PMID: 15924496]

[139] Breuer O, Sundararaj U. Big returns from small fibers: a review of polymer/carbon nanotube composites. Polym Compos 2004; 25(6): $630-45$. [http://dx.doi.org/10.1002/pc.20058]

[140] Bauhofer W, Kovacs JZ. A review and analysis of electrical percolation in carbon nanotube polymer composites. Compos Sci Technol 2009; 69(10): 1486-98.

[http://dx.doi.org/10.1016/j.compscitech.2008.06.018]

[141] Qian D, Dickey EC, Andrews R, Rantell T. Load transfer and deformation mechanisms in carbon nanotube-polystyrene composites. Appl Phys Lett 2000; 76(20): 2868-70. [http://dx.doi.org/10.1063/1.126500]

[142] Coleman JN, Khan U, Gun'ko YK. Mechanical reinforcement of polymers using carbon nanotubes. Adv Mater 2006; 18(6): 689-706. [http://dx.doi.org/10.1002/adma.200501851]

[143] Coleman JN, Khan U, Blau WJ, Gun'ko YK. Small but strong: a review of the mechanical properties of carbon nanotube-polymer composites. Carbon 2006; 44(9): 1624-52. [http://dx.doi.org/10.1016/j.carbon.2006.02.038]

[144] Supronowicz PR, Ajayan PM, Ullmann KR, Arulanandam BP, Metzger DW, Bizios R. Novel current-conducting composite substrates for exposing osteoblasts to alternating current stimulation. J Biomed Mater Res 2002; 59(3): 499-506. [http://dx.doi.org/10.1002/jbm.10015] [PMID: 11774308]

[145] Keremidarska M, Hristova K, Hikov T, et al. Development of polymer/nanodiamond composite coatings to control cell adhesion, growth, and functions. In: Iglič Aleš, Kulkarni Chandrashekhar V, Rappolt Michael, Eds. Advances in Planar Lipid Bilayers and Liposomes. Amsterdam: Elsevier Inc 2015; 22: pp. 1-26.

[http://dx.doi.org/10.1016/bs.adplan.2015.01.001]

[146] Mochalin VN, Gogotsi Y. Nanodiamond-Polymer Composites. Diamond Related Materials 2015; 58: $161-71$. [http://dx.doi.org/10.1016/j.diamond.2015.07.003]

[147] Zhang Q, Mochalin VN, Neitzel I, et al. Fluorescent PLLA-nanodiamond composites for bone tissue engineering. Biomaterials 2011; 32(1): 87-94. [http://dx.doi.org/10.1016/j.biomaterials.2010.08.090] [PMID: 20869765]

[148] Chawla KK. Ceramic matrix composites. US: Springer 1998. [http://dx.doi.org/10.1007/978-1-4757-2966-5_7]

[149] Xie Y, Li H, Zhang C, Gu X, Zheng X, Huang L. Graphene-reinforced calcium silicate coatings for load-bearing implants. Biomed Mater 2014; 9(2): 025009 [http://dx.doi.org/10.1088/1748-6041/9/2/025009] [PMID: 24518251]

[150] Tatavarty R, Ding H, Lu G, Taylor RJ, Bi X. Synergistic acceleration in the osteogenesis of human mesenchymal stem cells by graphene oxide-calcium phosphate nanocomposites. Chem Commun (Camb) 2014; 50(62): 8484-7. [http://dx.doi.org/10.1039/C4CC02442G] [PMID: 24891127]

[151] Porwal H, Grasso S, Cordero-Arias L, Li C, Boccaccini AR, Reece MJ. Processing and bioactivity of 45S5 Bioglass ${ }^{\circledR}$-graphene nanoplatelets composites. J Mater Sci Mater Med 2014; 25(6): 1403-13. [http://dx.doi.org/10.1007/s10856-014-5172-x] [PMID: 24519757]

[152] Fan Z, Wang J, Wang Z, et al. One-pot synthesis of graphene/hydroxyapatite nanorod composite for tissue engineering. Carbon 2014; 66: 407-16. [http://dx.doi.org/10.1016/j.carbon.2013.09.016]

[153] White AA, Best SM, Kinloch IA. Hydroxyapatite-carbon nanotube composites for biomedical applications: a review. Int J Appl Ceramic Technol 2007; 4(1): 1-13.

[http://dx.doi.org/10.1111/j.1744-7402.2007.02113.x] 
[154] Lu X, Qiu T, Wang XF, et al. Preparation of foam-like carbon nanotubes/hydroxyapatite composite scaffolds with superparamagnetic properties. Appl Surf Sci 2012; 262: 227-30. [http://dx.doi.org/10.1016/j.apsusc.2012.06.041]

[155] Zhao B, Hu H, Mandal SK, Haddon RC. A bone mimic based on the self-assembly of hydroxyapatite on chemically functionalized singlewalled carbon nanotubes. Chem Mater 2005; 17(12): 3235-41. [http://dx.doi.org/10.1021/cm0500399]

[156] Mukherjee S, Sen S, Chanda A. Mechanical and in vitro performance of CNT reinforced hydroxyapatite prepared by a shear mixing method. J Nanomed Nanotechnol 2013.

[http://dx.doi.org/10.4172/2157-7439.1000169]

[157] Mata D, Horovistiz AL, Branco I, et al. Carbon nanotube-based bioceramic grafts for electrotherapy of bone. Mater Sci Eng C Mater Biol Appl 2014; 34: 360-8. [http://dx.doi.org/10.1016/j.msec.2013.09.028] [PMID: 24268270]

[158] Chen L, Tang CY, Ku H S-1, Tsui CP, Chen X. Microwave sintering and characterization of polypropylene/multi-walled carbon nanotube/hydroxyapatite composites. Compos Part B Eng 2014; 56: 504-11. [http://dx.doi.org/10.1016/j.compositesb.2013.08.005]

[159] Niu L, Kua H, Chua DH. Bonelike apatite formation utilizing carbon nanotubes as template. Langmuir 2010; 26(6): 4069-73. [http://dx.doi.org/10.1021/la9034722] [PMID: 20020722]

[160] Emohare O, Rushton N. Self-assembled apatite on multiwalled carbon nanotubes substrates support osteogenic cell function. J Biomed Mater Res B Appl Biomater 2014; 102(3): 543-50. [http://dx.doi.org/10.1002/jbm.b.33033] [PMID: 24123858]

[161] Meng D, Rath SN, Mordan N, Salih V, Kneser U, Boccaccini AR. In vitro evaluation of 45S5 Bioglass ${ }^{\circledR}$-derived glass-ceramic scaffolds coated with carbon nanotubes. J Biomed Mater Res A 2011; 99(3): 435-44. [http://dx.doi.org/10.1002/jbm.a.33185] [PMID: 21887738]

[162] Misra SK, Ohashi F, Valappil SP, et al. Characterization of carbon nanotube (MWCNT) containing P(3HB)/bioactive glass composites for tissue engineering applications. Acta Biomater 2010; 6(3): 735-42. [http://dx.doi.org/10.1016/j.actbio.2009.09.023] [PMID: 19800427]

[163] Touri R, Moztarzadeh F, Sadeghian Z, Bizari D, Tahriri M, Mozafari M. The use of carbon nanotubes to reinforce 45S5 bioglass-based scaffolds for tissue engineering applications. Biomed Res Int 2013; 2013: 8. Article ID 465086. [http://dx.doi.org/10.1155/2013/465086]

[164] Boccaccini AR, Chicatun F, Cho J, et al. Carbon nanotube coatings on bioglass-based tissue engineering scaffolds. Adv Funct Mater 2007; 17(15): 2815-22. [http://dx.doi.org/10.1002/adfm.200600887]

[165] Cho J, Cannio M, Boccaccini AR. The electrophoretic deposition of Bioglass ${ }^{\circledR} /$ carbon nanotube composite layers for bioactive coatings. Int J Mater Prod Technol 2009; 35(3-4): 260-70. [http://dx.doi.org/10.1504/IJMPT.2009.025680]

[166] Shuai C, Liu T, Gao C, Feng P, Peng S. Mechanical reinforcement of diopside bone scaffolds with carbon nanotubes. Int J Mol Sci 2014; 15(10): 19319-29. [http://dx.doi.org/10.3390/ijms151019319] [PMID: 25342324]

[167] Wei G, Ma PX. Structure and properties of nano-hydroxyapatite/polymer composite scaffolds for bone tissue engineering. Biomaterials 2004; 25(19): 4749-57. [http://dx.doi.org/10.1016/j.biomaterials.2003.12.005] [PMID: 15120521]

[168] Furuzono T, Kishida A, Tanaka J. Nano-scaled hydroxyapatite/polymer composite I. Coating of sintered hydroxyapatite particles on poly $(\gamma-$ methacryloxypropyl trimethoxysilane)grafted silk fibroin fibers through chemical bonding. J Mater Sci Mater Med 2004; 15(1): 19-23. [http://dx.doi.org/10.1023/B:JMSM.0000010093.39298.5a] [PMID: 15338587]

[169] Sun F, Zhou H, Lee J. Various preparation methods of highly porous hydroxyapatite/polymer nanoscale biocomposites for bone regeneration. Acta Biomater 2011; 7(11): 3813-28. [http://dx.doi.org/10.1016/j.actbio.2011.07.002] [PMID: 21784182]

[170] Liao CZ, Wong HM, Yeung KW, Tjong SC. The development, fabrication, and material characterization of polypropylene composites reinforced with carbon nanofiber and hydroxyapatite nanorod hybrid fillers. Int J Nanomedicine 2014; 9: $1299-310$. [PMID: 24648729]

[171] Mei F, Zhong J, Yang X, et al. Improved biological characteristics of poly(L-lactic acid) electrospun membrane by incorporation of multiwalled carbon nanotubes/hydroxyapatite nanoparticles. Biomacromolecules 2007; 8(12): 3729-35. [http://dx.doi.org/10.1021/bm7006295] [PMID: 18020395]

[172] Singh MK, Shokuhfar T, Gracio JJ, et al. Hydroxyapatite modified with carbon nanotube-reinforced Poly (methyl methacrylate): a novel nanocomposite material for biomedical applications. Adv Funct Mater 2008; 9999: 1-7.

[173] Dubey N, Bentini R, Islam I, Cao T, Neto AHC, Rosa V. Graphene: A versatile carbon-based material for bone tissue engineering. Stem Cells Int 2015; 2015: 12. Article ID 804213. 
[http://dx.doi.org/10.1155/2015/804213]

[174] Deligianni DD. Multiwalled carbon nanotubes enhance human bone marrow mesenchymal stem cells spreading but delay their proliferation in the direction of differentiation acceleration. Cell Adhes Migr 2014; 8(6): 558-62. [http://dx.doi.org/10.4161/cam.32124] [PMID: 25482646]

[175] Yang L, Sheldon BW, Webster TJ. Orthopedic nano diamond coatings: control of surface properties and their impact on osteoblast adhesion and proliferation. J Biomed Mater Res A 2009; 91(2): 548-56. [http://dx.doi.org/10.1002/jbm.a.32227] [PMID: 18985788]

[176] Zanello LP, Zhao B, Hu H, Haddon RC. Bone cell proliferation on carbon nanotubes. Nano Lett 2006; 6(3): 562-7. [http://dx.doi.org/10.1021/n1051861e] [PMID: 16522063]

[177] Abarrategi A, Gutiérrez MC, Moreno-Vicente C, et al. Multiwall carbon nanotube scaffolds for tissue engineering purposes. Biomaterials 2008; 29(1): 94-102. [http://dx.doi.org/10.1016/j.biomaterials.2007.09.021] [PMID: 17928048]

[178] Akasaka T, Watari F, Sato Y, Tohji K. Apatite formation on carbon nanotubes. Mater Sci Eng C 2006; 26(4): 675-8. [http://dx.doi.org/10.1016/j.msec.2005.03.009]

[179] Balani K, Anderson R, Laha T, et al. Plasma-sprayed carbon nanotube reinforced hydroxyapatite coatings and their interaction with human osteoblasts in vitro. Biomaterials 2007; 28(4): 618-24. [http://dx.doi.org/10.1016/j.biomaterials.2006.09.013] [PMID: 17007921]

[180] Giannona S, Firkowska I, Rojas-Chapana J, Giersig M. Vertically aligned carbon nanotubes as cytocompatible material for enhanced adhesion and proliferation of osteoblast-like cells. J Nanosci Nanotechnol 2007; 7(4-5): 1679-83. [http://dx.doi.org/10.1166/jnn.2007.454] [PMID: 17450943]

[181] Wang W, Watari F, Omori M, et al. Mechanical properties and biological behavior of carbon nanotube/polycarbosilane composites for implant materials. J Biomed Mater Res B Appl Biomater 2007; 82(1): 223-30. [http://dx.doi.org/10.1002/jbm.b.30724] [PMID: 17183562]

[182] Ciapetti G, Granchi D, Devescovi V, et al. Enhancing osteoconduction of PLLA-based nanocomposite scaffolds for bone regeneration using different biomimetic signals to MSCs. Int J Mol Sci 2012; 13(2): 2439-58. [http://dx.doi.org/10.3390/ijms13022439] [PMID: 22408463]

[183] Mahmood M, Villagarcia H, Dervishi E, et al. Role of carbonaceous nanomaterials in stimulating osteogenesis in mammalian bone cells. J Mater Chem B Mater Biol Med 2013; 1(25): 3220-30. [http://dx.doi.org/10.1039/c3tb20248h]

[184] Bajaj P, Khang D, Webster TJ. Control of spatial cell attachment on carbon nanofiber patterns on polycarbonate urethane. Int J Nanomedicine 2006; 1(3): 361-5. [PMID: 17717976]

[185] Lin C, Wang Y, Lai Y, et al. Incorporation of carboxylation multiwalled carbon nanotubes into biodegradable poly(lactic-co-glycolic acid) for bone tissue engineering. Colloids Surf B Biointerfaces 2011; 83(2): 367-75. [http://dx.doi.org/10.1016/j.colsurfb.2010.12.011] [PMID: 21208787]

[186] Lee HH, Sang Shin U, Lee JH, Kim HW. Biomedical nanocomposites of poly(lactic acid) and calcium phosphate hybridized with modified carbon nanotubes for hard tissue implants. J Biomed Mater Res B Appl Biomater 2011; 98(2): 246-54.

[http://dx.doi.org/10.1002/jbm.b.31846] [PMID: 21591250]

[187] Bhattacharya M, Wutticharoenmongkol-Thitiwongsawet P, Hamamoto DT, et al. Bone formation on carbon nanotube composite. J Biomed Mater Res A 2011; 96(1): 75-82. [http://dx.doi.org/10.1002/jbm.a.32958] [PMID: 21105154]

[188] Kasai T, Matsumura S, Iizuka T, et al. Carbon nanohorns accelerate bone regeneration in rat calvarial bone defect. Nanotechnology 2011; 22(6): 065102.

[http://dx.doi.org/10.1088/0957-4484/22/6/065102] [PMID: 21212475]

[189] Xing Z, Pedersen TO, Wu X, et al. Biological effects of functionalizing copolymer scaffolds with nanodiamond particles. Tissue Eng Part A 2013; 19(15-16): 1783-91.

[http://dx.doi.org/10.1089/ten.tea.2012.0336] [PMID: 23574424]

[190] Brady MA, Renzing A, Douglas TE, et al. Development of composite poly (lactide-co-glycolide)-nanodiamond scaffolds for bone cell growth. J Nanosci Nanotechnol 2015; 15(2): 1060-9. [http://dx.doi.org/10.1166/jnn.2015.9745] [PMID: 26353613]

[191] Lam CW, James JT, McCluskey R, Arepalli S, Hunter RL. A review of carbon nanotube toxicity and assessment of potential occupational and environmental health risks. Crit Rev Toxicol 2006; 36(3): 189-217. [http://dx.doi.org/10.1080/10408440600570233] [PMID: 16686422]

[192] Clichici S, Filip A. In vivo assessment of nanomaterials toxicity. In: Soloneski Sonia, Larramendy Marcelo L, Eds. Nanomaterials - Toxicity and Risk Assessment. Rijeka: InTech 2015. [http://dx.doi.org/10.5772/60707]

[193] Lanone S, Andujar P, Kermanizadeh A, Boczkowski J. Determinants of carbon nanotube toxicity. Adv Drug Deliv Rev 2013; 65(15): $2063-9$. 
[http://dx.doi.org/10.1016/j.addr.2013.07.019] [PMID: 23928473]

[194] Awasthi KK, John PJ, Awasthi A, Awasthi K. Multi walled carbon nano tubes induced hepatotoxicity in Swiss albino mice. Micron 2013; 44: 359-64.

[http://dx.doi.org/10.1016/j.micron.2012.08.008] [PMID: 23000350]

[195] Fenoglio I, Aldieri E, Gazzano E, et al. Thickness of multiwalled carbon nanotubes affects their lung toxicity. Chem Res Toxicol 2012; 25(1): 74-82. [http://dx.doi.org/10.1021/tx200255h] [PMID: 22128750]

[196] Wang X, Jia G, Wang H, et al. Diameter effects on cytotoxicity of multi-walled carbon nanotubes. J Nanosci Nanotechnol 2009; 9(5): 3025-33. [http://dx.doi.org/10.1166/jnn.2009.025] [PMID: 19452965]

[197] Casals E, Vázquez-Campos S, Bastús NG, Puntes V. Distribution and potential toxicity of engineered inorganic nanoparticles and carbon nanostructures in biological systems. TrAC Trends Anal Chem 2008; 27(8): 672-83. [http://dx.doi.org/10.1016/j.trac.2008.06.004]

[198] Tian F, Cui D, Schwarz H, Estrada GG, Kobayashi H. Cytotoxicity of single-wall carbon nanotubes on human fibroblasts. Toxicol In Vitro 2006; 20(7): 1202-12 [http://dx.doi.org/10.1016/j.tiv.2006.03.008] [PMID: 16697548]

[199] Jia G, Wang H, Yan L, et al. Cytotoxicity of carbon nanomaterials: single-wall nanotube, multi-wall nanotube, and fullerene. Environ Sci Technol 2005; 39(5): 1378-83. [http://dx.doi.org/10.1021/es0487291] [PMID: 15787380]

[200] Warheit DB, Laurence BR, Reed KL, Roach DH, Reynolds GA, Webb TR. Comparative pulmonary toxicity assessment of single-wall carbon nanotubes in rats. Toxicol Sci 2004; 77(1): 117-25. [http://dx.doi.org/10.1093/toxsci/kfg228] [PMID: 14514968]

[201] Lam C-W, James JT, McCluskey R, Hunter RL. Pulmonary toxicity of single-wall carbon nanotubes in mice 7 and 90 days after intratracheal instillation. Toxicol Sci 2004; 77(1): 126-34. [http://dx.doi.org/10.1093/toxsci/kfg243] [PMID: 14514958]

[202] Köhler AR, Som C, Helland A, Gottschalk F. Studying the potential release of carbon nanotubes throughout the application life cycle. J Clean Prod 2008; 16(8): 927-37. [http://dx.doi.org/10.1016/j.jclepro.2007.04.007]

[203] Marchesan S, Kostarelos K, Bianco A, Prato M. The winding road for carbon nanotubes in nanomedicine. Mater Today 2015; 18(1): 12-9. [http://dx.doi.org/10.1016/j.mattod.2014.07.009]

[204] Riviere JE. Pharmacokinetics of nanomaterials: an overview of carbon nanotubes, fullerenes and quantum dots. Wiley Interdiscip Rev Nanomed Nanobiotechnol 2009; 1(1): 26-34. [http://dx.doi.org/10.1002/wnan.24] [PMID: 20049776]

[205] Ali-Boucetta H, Kostarelos K. Pharmacology of carbon nanotubes: toxicokinetics, excretion and tissue accumulation. Adv Drug Deliv Rev 2013; 65(15): 2111-9. [http://dx.doi.org/10.1016/j.addr.2013.10.004] [PMID: 24184372]

[206] Muller J, Delos M, Panin N, Rabolli V, Huaux F, Lison D. Absence of carcinogenic response to multiwall carbon nanotubes in a 2-year bioassay in the peritoneal cavity of the rat. Toxicol Sci 2009; 110(2): 442-8. [http://dx.doi.org/10.1093/toxsci/kfp100] [PMID: 19429663]

[207] Deng X, Jia G, Wang H, et al. Translocation and fate of multi-walled carbon nanotubes in vivo. Carbon 2007; 45(7): 1419-24. [http://dx.doi.org/10.1016/j.carbon.2007.03.035]

[208] Elgrabli D, Floriani M, Abella-Gallart S, et al. Biodistribution and clearance of instilled carbon nanotubes in rat lung. Part Fibre Toxicol 2008; 5(20): 20.

[http://dx.doi.org/10.1186/1743-8977-5-20] [PMID: 19068117]

[209] Muller J, Huaux F, Moreau N, et al. Respiratory toxicity of multi-wall carbon nanotubes. Toxicol Appl Pharmacol 2005; 207(3): 221-31. [http://dx.doi.org/10.1016/j.taap.2005.01.008] [PMID: 16129115]

[210] Yang S-t, Guo W, Lin Y, et al. Biodistribution of pristine single-walled carbon nanotubes in vivo. J Phys Chem C 2007; 111(48): 17761-4. [http://dx.doi.org/10.1021/jp070712c]

[211] Lacerda L, Ali-Boucetta H, Herrero MA, et al. Tissue histology and physiology following intravenous administration of different types of functionalized multiwalled carbon nanotubes. Nanomedicine (Lond) 2008; 3(2): 149-61. [http://dx.doi.org/10.2217/17435889.3.2.149]

[212] Battigelli A, Ménard-Moyon C, Da Ros T, Prato M, Bianco A. Endowing carbon nanotubes with biological and biomedical properties by chemical modifications. Adv Drug Deliv Rev 2013; 65(15): 1899-920. [http://dx.doi.org/10.1016/j.addr.2013.07.006] [PMID: 23856410]

[213] Al-Jamal KT, Nunes A, Methven L, et al. Degree of chemical functionalization of carbon nanotubes determines tissue distribution and excretion profile. Angew Chem Int Ed Engl 2012; 51(26): 6389-93. [http://dx.doi.org/10.1002/anie.201201991] [PMID: 22623333] 
[214] Liu X, Hurt RH, Kane AB. Biodurability of single-walled carbon nanotubes depends on surface functionalization. Carbon NY 2010; 48(7): 1961-9. [http://dx.doi.org/10.1016/j.carbon.2010.02.002] [PMID: 20352066]

[215] Zhao X, Liu R. Recent progress and perspectives on the toxicity of carbon nanotubes at organism, organ, cell, and biomacromolecule levels. Environ Int 2012; 40: 244-55. [http://dx.doi.org/10.1016/j.envint.2011.12.003] [PMID: 22244841]

[216] Zhang T, Tang M, Kong L, et al. Surface modification of multiwall carbon nanotubes determines the pro-inflammatory outcome in macrophage. J Hazard Mater 2015; 284: 73-82. [http://dx.doi.org/10.1016/j.jhazmat.2014.11.013] [PMID: 25463220]

[217] Rahman I, MacNee W. Oxidative stress and regulation of glutathione in lung inflammation. Eur Respir J 2000; 16(3): 534-54. [http://dx.doi.org/10.1034/j.1399-3003.2000.016003534.x] [PMID: 11028671]

[218] Bottini M, Bruckner S, Nika K, et al. Multi-walled carbon nanotubes induce T lymphocyte apoptosis. Toxicol Lett 2006; 160(2): 121-6. [http://dx.doi.org/10.1016/j.toxlet.2005.06.020] [PMID: 16125885]

[219] Vittorio O, Raffa V, Cuschieri A. Influence of purity and surface oxidation on cytotoxicity of multiwalled carbon nanotubes with human neuroblastoma cells. Nanomedicine (Lond) 2009; 5(4): 424-31. [PMID: 19341817]

[220] Tabet L, Bussy C, Setyan A, et al. Coating carbon nanotubes with a polystyrene-based polymer protects against pulmonary toxicity. Part Fibre Toxicol 2011; 8(3): 3 . [http://dx.doi.org/10.1186/1743-8977-8-3] [PMID: 21255417]

[221] Murphy FA, Schinwald A, Poland CA, Donaldson K. The mechanism of pleural inflammation by long carbon nanotubes: interaction of long fibres with macrophages stimulates them to amplify pro-inflammatory responses in mesothelial cells. Part Fibre Toxicol 2012; 9(8): 8. [http://dx.doi.org/10.1186/1743-8977-9-8] [PMID: 22472194]

[222] Yamashita K, Yoshioka Y, Higashisaka K, et al. Carbon nanotubes elicit DNA damage and inflammatory response relative to their size and shape. Inflammation 2010; 33(4): 276-80. [http://dx.doi.org/10.1007/s10753-010-9182-7] [PMID: 20174859]

[223] Magrez A, Kasas S, Salicio V, et al. Cellular toxicity of carbon-based nanomaterials. Nano Lett 2006; 6(6): 1121-5. [http://dx.doi.org/10.1021/n1060162e] [PMID: 16771565]

[224] Muller J, Huaux F, Fonseca A, et al. Structural defects play a major role in the acute lung toxicity of multiwall carbon nanotubes: toxicological aspects. Chem Res Toxicol 2008; 21(9): 1698-705 [http://dx.doi.org/10.1021/tx800101p] [PMID: 18636756]

[225] Saxena RK, Williams W, Mcgee JK, Daniels MJ, Boykin E, Gilmour Dr MI. Enhanced in vitro and in vivo toxicity of poly-dispersed acidfunctionalized single-wall carbon nanotubes. Nanotoxicology 2007; 1(4): 291-300. [http://dx.doi.org/10.1080/17435390701803110]

[226] Chen W, Xiong Q, Ren Q, Guo Y, Li G. Can amino-functionalized carbon nanotubes carry functional nerve growth factor? Neural Regen Res 2014; $9(3): 285-92$

[http://dx.doi.org/10.4103/1673-5374.128225] [PMID: 25206814]

[227] Liu Y, Ren L, Yan D, Zhong W. Mechanistic study on the reduction of SWCNT-induced cytotoxicity by albumin coating. Part Part Syst Charact 2014; 31(12): 1244-51. [http://dx.doi.org/10.1002/ppsc.201400145] [PMID: 25580058]

[228] Wang X, Xia T, Duch MC, et al. Pluronic F108 coating decreases the lung fibrosis potential of multiwall carbon nanotubes by reducing lysosomal injury. Nano Lett 2012; 12(6): 3050-61. [http://dx.doi.org/10.1021/n1300895y] [PMID: 22546002]

[229] Paget V, Sergent JA, Grall R, et al. Carboxylated nanodiamonds are neither cytotoxic nor genotoxic on liver, kidney, intestine and lung human cell lines. Nanotoxicology 2014; 8(1): 46-56. [http://dx.doi.org/10.3109/17435390.2013.855828]

[230] Mytych J, Lewinska A, Bielak-Zmijewska A, Grabowska W, Zebrowski J, Wnuk M. Nanodiamond-mediated impairment of nucleolar activity is accompanied by oxidative stress and DNMT2 upregulation in human cervical carcinoma cells. Chem Biol Interact 2014; 220: 51-63. [http://dx.doi.org/10.1016/j.cbi.2014.06.004] [PMID: 24928743]

[231] Bang JJ, Guerrero PA, Lopez DA, Murr LE, Esquivel EV. Carbon nanotubes and other fullerene nanocrystals in domestic propane and natural gas combustion streams. J Nanosci Nanotechnol 2004; 4(7): 716-8. [http://dx.doi.org/10.1166/jnn.2004.095] [PMID: 15570950]

[232] Murr L, Bang JJ, Lopez DA, et al. Carbon nanotubes and nanocrystals in methane combustion and the environmental implications. J Mater Sci 2004; 39(6): 2199-204. [http://dx.doi.org/10.1023/B:JMSC.0000017787.53545.b7]

[233] Murr LE, Bang JJ, Esquivel EV, Guerrero PA, Lopez DA. Carbon nanotubes, nanocrystal forms, and complex nanoparticle aggregates in common fuel-gas combustion sources and the ambient air. J Nanopart Res 2004; 6(2): 241-51. [http://dx.doi.org/10.1023/B:NANO.0000034651.91325.40] 
[234] Baron PA, Foley M, Maynard AD. Evaluation of aerosol release during the handling of unrefined single walled carbon nanotube material. National Technical Information Service 2003.

[235] Gernand JM, Casman EA. A meta-analysis of carbon nanotube pulmonary toxicity studie show physical dimensions and impurities affect the toxicity of carbon nanotubes. Risk Anal 2014; 34(3): 583-97. [http://dx.doi.org/10.1111/risa.12109] [PMID: 24024907]

[236] Poland CA, Duffin R, Kinloch I, et al. Carbon nanotubes introduced into the abdominal cavity of mice show asbestos-like pathogenicity in a pilot study. Nat Nanotechnol 2008; 3(7): 423-8. [http://dx.doi.org/10.1038/nnano.2008.111] [PMID: 18654567]

[237] Murphy FA, Poland CA, Duffin R, et al. Length-dependent retention of carbon nanotubes in the pleural space of mice initiates sustained inflammation and progressive fibrosis on the parietal pleura. Am J Pathol 2011; 178(6): 2587-600. [http://dx.doi.org/10.1016/j.ajpath.2011.02.040] [PMID: 21641383]

[238] Harper S, Wohlleben W, Doa M, et al. Measuring nanomaterial release from carbon nanotube composites: review of the state of the science. J Phys Conf Ser 2015; 617: 012026. [http://dx.doi.org/10.1088/1742-6596/617/1/012026]

[239] Huczko A, Lange H. Carbon nanotubes: experimental evidence for a null risk of skin irritation and allergy. Fullerene Sci Technol 2001; 9(2): 247-50. [http://dx.doi.org/10.1081/FST-100102972]

[240] Kitahara H, Kuboki Y, Takita H, Akasaka T, Watari F, Inoue N. Culture of es cells and mesenchymal stem cells on carbon nanotube scaffolds. Nano Biomedicine 2010; 2(2): 81-92.

[241] Brunner EW, Jurewicz I, Heister E, et al. Growth and proliferation of human embryonic stem cells on fully synthetic scaffolds based on carbon nanotubes. ACS Appl Mater Interfaces 2014; 6(4): 2598-603. [http://dx.doi.org/10.1021/am405097w] [PMID: 24456005]

[242] Namgung S, Baik KY, Park J, Hong S. Controlling the growth and differentiation of human mesenchymal stem cells by the arrangement of individual carbon nanotubes. ACS Nano 2011; 5(9): 7383-90. [http://dx.doi.org/10.1021/nn2023057] [PMID: 21819114]

(C) Perkins and Naderi; Licensee Bentham Open

This is an open access article licensed under the terms of the Creative Commons Attribution-Non-Commercial 4.0 International Public License (CC BY-NC 4.0) (https://creativecommons.org/licenses/by-nc/4.0/legalcode), which permits unrestricted, non-commercial use, distribution and reproduction in any medium, provided the work is properly cited. 